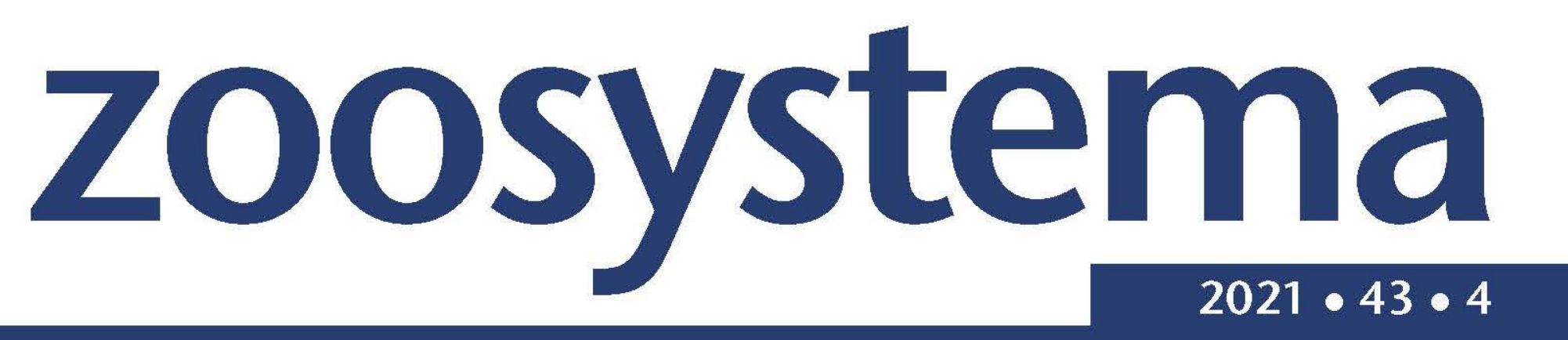

Out on a limb: novel morphology and position on appendages of two new genera and three new species of ectoparasitic isopods (Epicaridea: Dajidae) infesting isopod and decapod hosts

Jason D. WILLIAMS \& Christopher B. BOYKO

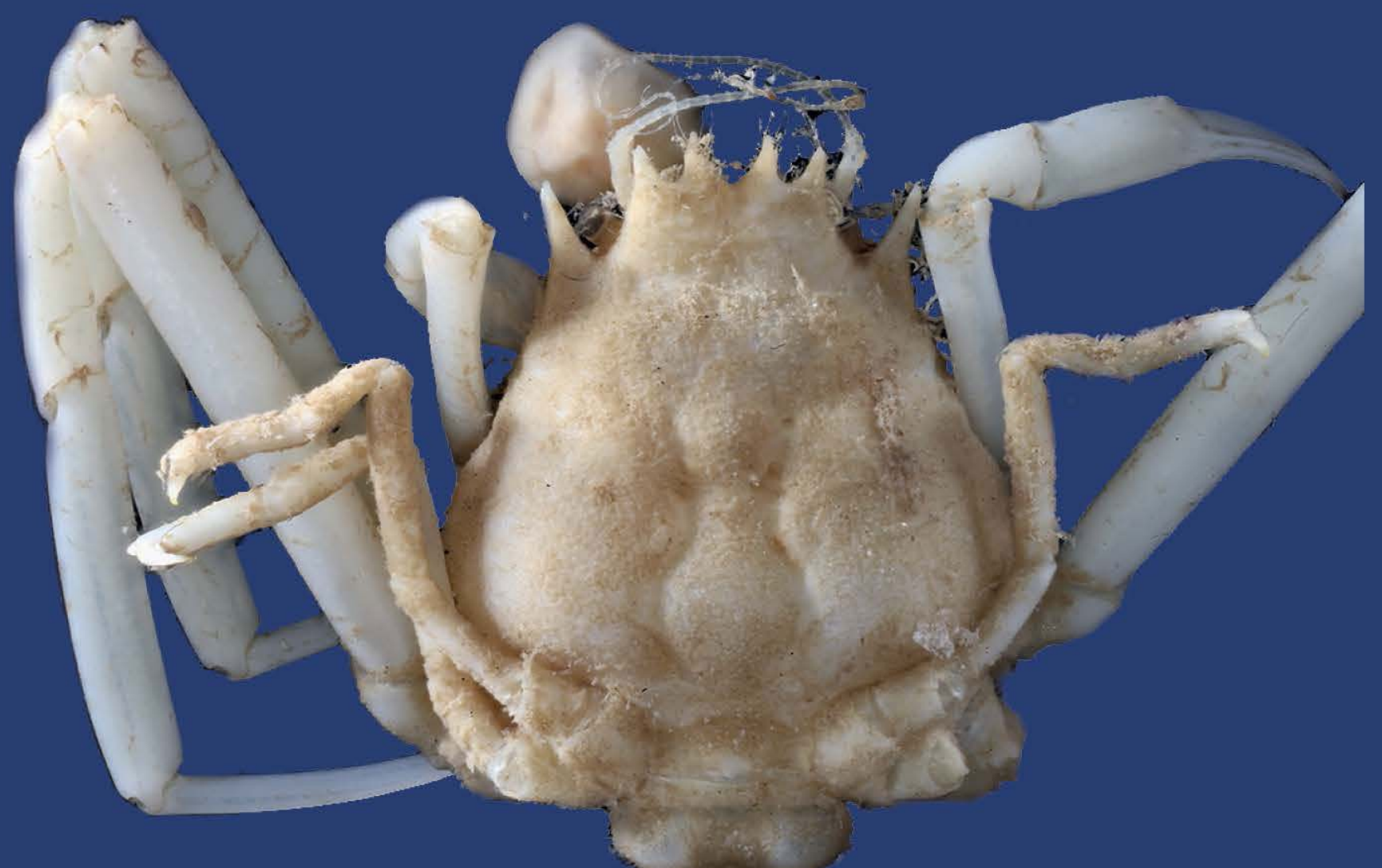


Directeur de LA publication / Publication diRECTOR: Bruno David

Président du Muséum national d'Histoire naturelle

RÉDACTRICE EN CHEF / EDITOR-IN-CHIEF: Laure Desutter-Grandcolas

ASSISTANTE DE RÉDACTION / AsSISTANT EDITOR: Anne Mabille (zoosyst@mnhn.fr)

Mise en PAge / PAge LAYOUt: Anne Mabille

COMITÉ SCIENTIFIQUE / SCIENTIFIC BOARD:

James Carpenter (AMNH, New York, États-Unis)

Maria Marta Cigliano (Museo de La Plata, La Plata, Argentine)

Henrik Enghoff (NHMD, Copenhague, Danemark)

Rafael Marquez (CSIC, Madrid, Espagne)

Peter $\mathrm{Ng}$ (University of Singapore)

Jean-Yves Rasplus (INRA, Montferrier-sur-Lez, France)

Jean-François Silvain (IRD, Gif-sur-Yvette, France)

Wanda M. Weiner (Polish Academy of Sciences, Cracovie, Pologne)

John Wenzel (The Ohio State University, Columbus, États-Unis)

COUVERTURE / COVER:

Akrophryxus milvus n. gen., n. sp., holotype female, MNHN-IU-2014-20314, attached to Ethusa machaera Castro, 2005, macropod images.

Zoosystema est indexé dans / Zoosystema is indexed in:

- Science Citation Index Expanded (SciSearch $\left.{ }^{\circledR}\right)$

- ISI Alerting Services ${ }^{\circledR}$

- Current Contents ${ }^{\circledR} /$ Agriculture, Biology, and Environmental Sciences ${ }^{\circledR}$

- Scopus ${ }^{\circledR}$

Zoosystema est distribué en version électronique par / Zoosystema is distributed electronically by:

- BioOne ${ }^{\circledR}$ (http://www.bioone.org)

Les articles ainsi que les nouveautés nomenclaturales publiés dans Zoosystema sont référencés par / Articles and nomenclatural novelties published in Zoosystema are referenced by:

- ZooBank ${ }^{\circledR}$ (http://zoobank.org)

Zoosystema est une revue en flux continu publiée par les Publications scientifiques du Muséum, Paris / Zoosystema is a fast track journal published by the Museum Science Press, Paris

Les Publications scientifiques du Muséum publient aussi / The Museum Science Press also publish:

Adansonia, Geodiversitas, Anthropozoologica, European Journal of Taxonomy, Naturae, Cryptogamie sous-sections Algologie, Bryologie, Mycologie.

Diffusion - Publications scientifiques Muséum national d'Histoire naturelle

CP $41-57$ rue Cuvier F-75231 Paris cedex 05 (France)

Tél.: 33 (0)1 40794805 / Fax: 33 (0)1 40793840

diff.pub@mnhn.fr / https://sciencepress.mnhn.fr

(C) Publications scientifiques du Muséum national d'Histoire naturelle, Paris, 2021

ISSN (imprimé / print): 1280-9551/ ISSN (électronique / electronic): 1638-9387 


\section{Out on a limb: novel morphology and position on appendages of two new genera and three new species of ectoparasitic isopods (Epicaridea: Dajidae) infesting isopod and decapod hosts}

Jason D. WILLIAMS

Department of Biology, Hofstra University, 1000 Hempstead Turnpike, Hempstead, NY 11549 (USA) jason.d.williams@hofstra.edu (corresponding author)

Christopher B. BOYKO Department of Biology, Hofstra University, 1000 Hempstead Turnpike, Hempstead, NY 11549 (USA); and Division of Invertebrate Zoology, American Museum of Natural History, 200 Central Park West, New York, NY, 10024 (USA)

cboyko@amnh.org

Submitted on 20 March 2020 | Accepted on 22 June 2020 | Published on 16 February 2021

urn:Isid:zoobank.org:pub:4F2A16F1-B100-4236-AD31-945896D6F910

Williams J. D. \& Boyko C. B. 2021. - Out on a limb: novel morphology and position on appendages of two new genera and three new species of ectoparasitic isopods (Epicaridea: Dajidae) infesting isopod and decapod hosts. Zoosystema 43 (4): 79-100. https://doi.org/10.5252/zoosystema2021v43a4. http://zoosystema.com/43/4

\section{ABSTRACT}

Adult female dajid isopods are ectoparasites found on carapaces, within marsupia, or rarely attached to the eyestalks or pereopods of crustacean hosts. We describe two new genera and species whose females exhibit a novel spheroid shape and envelope antennules of hosts: Akrophryxus milvus n. gen., n. sp. parasitizing Ethusa machaera Castro, 2005 (Madagascar, c. $900 \mathrm{~m}$ ) and Telephryxus clypeus n. gen., n. sp. parasitizing Munidopsis crassa Smith, 1885 (Caribbean, c. 5000 m). Females of both species differ from other dajid species in their spheroid shape and a plate partially surrounding the host antennule; males are distinguished by reduction of pereopods. Females of $A$. milvus n. gen., n. sp. are distinguished from those of $T$. clypeus n. gen., n. sp. in possessing antennules and a triangular attachment plate with three holes (T. clypeus n. gen., n. sp. lacks antennules and the broad attachment plate has two medial holes). Males of $A$. milvus n. gen., n. sp. are distinguished from those of T. clypeus $\mathrm{n}$. gen., n. sp. in having only six pairs of pereopods, rudimentary antennules, single segmented antennae, and

KEY WORDS

Abyssal, Aegiochus, Ethusa, Ethusa,
Isopoda, life cycle, Munidopsis, new species, new genus. pleon fused to pereomere 7 (T. clypeus n. gen., n. sp. with rudimentary seventh pair of pereopods, large single segmented antennules, two segmented antennae, and pleon distinct from pereomere 7). Pre-molt epicaridium larvae and cryptoniscus larvae of $T$. clypeus n. gen., n. sp. are described. We also describe Aegophila cappa n. sp. found on pereopods of the isopod Aegiochus symmetrica (Richardson, 1905) (Bering Sea, c. 650 m), distinguished from the type species of Aegophila Bresciani, 1966 by oostegite morphology of the female, form of the antennae, and shape of the pleon of males. Tables with comparative characters for genera of Dajidae G. O. Sars, 1883 are provided. Dajid life cycles and development are reviewed. 


MOTS CLÉS
Abyssal,
Aegiochus,
Ethusa,
Isopoda,
cycle de vie,
Munidopsis,
antennule parasies
espèces nouvelles,
genres nouveaux.

\begin{abstract}
RÉSUMÉ
Suspendu à un fil: nouvelle morphologie et position sur les appendices de deux nouveaux genres et trois nouvelles espèces d'isopodes ectoparasites (Epicaridea: Dajidae) infestant des hôtes isopodes et décapodes. Les femelles adultes d'isopodes dajides sont des ectoparasites que l'on trouve sur les carapaces, au sein de marsupiums, ou plus rarement attachés aux pédoncules oculaires ou aux péréopodes des crustacés hôtes. Nous décrivons deux nouveaux genres et espèces dont les femelles présentent une forme sphérique nouvelle et enveloppent les antennules des hôtes: Akrophryxus milvus n. gen., n. sp. parasite d'Ethusa machaera Castro, 2005 (Madagascar, c. 900 m) et Telephryxus clypeus n. gen., n. sp. parasite de Munidopsis crassa Smith, 1885 (Caraïbes, c. $5000 \mathrm{~m}$ ). Les femelles des deux espèces se distinguent des autres espèces de dajides par leur forme sphérique et une plaque entourant partiellement l'antennule de l'hôte; les mâles se distinguent par la réduction des péréopodes. Les femelles de A. milvus n. gen., n. sp. se distinguent de celles de T. clypeus n. gen., n. sp. par la présence d'antennules et par une plaque de fixation triangulaire à trois orifices (T. clypeus n. gen., n. sp. n'a pas d'antennules et la large plaque de fixation a deux orifices médians). Les mâles de A. milvus n. gen., n. sp. se distinguent de ceux de T. clypeus n. gen., n. sp. par leur nombre réduit de péréopodes (seulement six paires), des antennules rudimentaires, des antennes unisegmentées et un pléon fusionné au péréomère 7 ( $T$. clypeus $\mathrm{n}$. gen., n. sp. a une septième paire de péréopodes rudimentaires, de grandes antennules unisegmentées, deux antennes segmentées et un pléon distinct du péréomère 7). Les larves epicaridium de pré-mues et les larves cryptoniscus de T. clypeus n. gen., n. sp. sont décrites. Nous décrivons également Aegophila cappa n. sp. trouvé sur les péréopodes de l'isopode Aegiochus symmetrica (Richardson, 1905) (mer de Béring, c. $650 \mathrm{~m}$ ), et qui se distingue de l'espèce type d'Aegophila Bresciani, 1966 par la morphologie des oostégites de la femelle, la forme des antennes et la forme du pléon des mâles. Des tableaux avec des caractères comparatifs pour les genres de Dajidae G. O. Sars, 1883 sont fournis. Les cycles de vie et le développement des dajides sont passés en revue.
\end{abstract}

\section{INTRODUCTION}

Attachment to the extremities, including appendages such as antennae and legs, would seem a risky strategy for ectoparasites of aquatic hosts. Although some protozoans and other small ectoparasites and epibionts are commonly found on such host structures or their setae (e.g. Lom 2005; Heiner \& Kristensen 2005), macroparasites are rarely attached in such positions. Rather, the bodies of most ectoparasites are closely applied to the bodies of their hosts or within protected regions (e.g. branchial chambers) and often exhibit adaptations (e.g. dorsoventral flattening, modified attachment structures) to withstand the hydrodynamic pressures that would otherwise dislodge them from hosts (e.g. Boxshall 2005a, b; Smit et al. 2014; Baillie et al. 2019). Other unusual sites of attachment are on the eye stalks of their crustacean hosts (Shields \& GómezGutiérrez 1996). Crustacean parasites that themselves parasitize other crustaceans are likewise usually found attached to the bodies of their hosts, either on the dorsal or ventral surfaces of the cephalon, the pereon or the pleon; however, there are a few highly modified spheroid or ovate macroparasites, such as certain rhizocephalans, tantulocarids, and copepods, that are known from extremities (e.g. antennules, antennae and pereopods) of their crustacean hosts (Boxshall \& Hayes 2019).

Rhizocephalans (Rhizocephala Müller, 1862) are mesoparasitic barnacles that include colonial forms, of which some species (e.g. Thompsonia japonica Häfele, 1911; Thylacoplethus porcellanus Hiller, Williams \& Boyko, 2015) can occur on the pereopods as well as the body of the host. An additional species, Thompsonia chuni Häfele, 1911, is known from the eyestalks of its hermit crab host (Häfele 1911; Hiller et al.
2015). Each mature externa (the reproductive portion of the body) of a colonial rhizocephalan is approximately $1-2 \mathrm{~mm}$ in length and is attached by a short stalk to an appendage of its host; however, it does not surround the appendage (Hiller et al. 2015). The spheroid externae of these species, like all rhizocephalans, erupt from the body of the host and are connected to an internal root system; they are not originally attached to the appendages (aside from the larval phase that is responsible for injection of the primordial cells and may settle on an appendage prior to the injection; see life cycles in Høeg \& Lützen 1995; Baeza et al. 2018).

Tantulocarids (Tantulocarida Boxshall \& Lincoln, 1983) are ectoparasites on a range of small crustacean hosts (copepods, peracarids and ostracods) and their life cycle includes sac-like adult female stages attached to the host (both parthenogenetic females and females in the sexual stage are sac-like; see background and life cycles in Huys et al. 1993; Boxshall 2005c; Baeza et al. 2018). Several species of tantulocarid parasites (e.g. Amphitantulus harpiniacheres Boxshall \& Vader, 1993; Microdajus tchesunovi Kolbasov \& Savchenko, 2009; M. langi Greve, 1965) attach to the antennules, antennae and/or pereopods of their tanaid or amphipod hosts. However, these species have also been found attached to the main body of their hosts (Grygier \& Sieg 1988; Boxshall \& Vader 1993; Kolbasov \& Savchenko 2009). There are a few tantulocarid species (e.g. Microdajus aporosus Grygier \& Sieg, 1988) that have only been reported from appendages (pereopods) of tanaids (Grygier \& Sieg 1988). Species of Microdajus Greve, 1965 are minute $(<1 \mathrm{~mm}$ in length) and are attached by a stalk to the appendage of their hosts (Boxshall \& Hayes 2019; Boyko et al. in press). 
The only other previously known crustacean parasites that may be appendage specialists are some species of mesoparasitic nicothoid copepods (Nicothoidae Dana, 1852; see review in Kakui 2016). In particular, two species (Nicorhiza humesi Lincoln \& Boxshall, 1983 and N. rockallensis Lincoln \& Boxshall, 1983) are found attached to the bases of pereopods 3-6 of their asellote isopod hosts (Lincoln \& Boxshall 1983). Adult females of Nicorhiza Lincoln \& Boxshall, 1983 and other genera in the "Rhizorhina group" (sensu Boxshall \& Halsey 2004) superficially resemble rhizocephalans, including convergently possessing an absorptive rootlet system within the host. These copepods are spheroid, relatively small (400-600 $\mu \mathrm{m}$ in length) and attach to hosts by a modified oral cone. The point of attachment to hosts for some nicothoids (e.g. species of Diexanthema Ritchie, 1975; see Boxshall \& Harrison 1988) remains unknown and other species might be found to vary in their position on hosts (sampling has been low for many) but none are known to surround the appendages of their hosts.

Among the parasitic isopods (Epicaridea Latreille, 1825), which likewise exclusively parasitize other crustaceans, there were no species previously found attached to the antennules and only one known to attach to pereopods of their hosts. Epicaridea contains two superfamilies (Bopyroidea Rafinesque, 1815 and Cryptoniscoidea Kossmann, 1880), species of which nearly all externally parasitize calanoid copepod hosts as their intermediate hosts and then parasitize one or more of a wide range of crustaceans (cirripedes, decapods, euphausiids, mysids, ostracods, peracarids) as definitive hosts. The most diverse family within Bopyroidea is Bopyridae Rafinesque, 1815 with over 600 species (Boyko et al. 2008a onwards), which are mostly ectoparasites in the branchial chambers of their definitive hosts, although some are also found attached to the ventral surfaces of host abdomens and a very few occur on other parts of hosts or are endoparasites (Trilles 1999; Williams \& Boyko 2012). Females of most bopyrid species have a dorsoventrally flattened form, as do those of species in Ionidae H. Milne Edwards, 1840 which are exclusively branchial chamber parasites (see Boyko et al. 2013), whereas females of species in Entoniscidae Kossmann, 1881 are endoparasitic and vermiform. Among the cryptoniscoids, there are many species in which sexually mature females exhibit a sac-like form (Trilles 1999), but they are irregular in shape, do not form a spheroid, and are typically found in the brood chamber or shell (for the case of barnacles) of hosts as primary parasites or hyperparasites of a wide range of hosts (Williams \& Boyko 2012).

Within Cryptoniscoidea the family Dajidae G. O. Sars, 1883 (Boyko et al. 2013) presently contains 56 species that typically possess a cryptoniscus larval stage with an oral sucker (see more in Remarks under Telephryxus clypeus n. gen., n. sp.) used to attach to the definitive host (see Gilson 1909; Coyle \& Mueller 1981; Gómez-Gutiérrez et al. 2017). Most species in this group are attached as adults to the dorsal carapace of their hosts, typically on caridean shrimp and euphausiids or occur in the marsupia of mysids (see G. O. Sars 1898; Wasmer 1988; Shimomura et al. 2005; Gómez-Gutiérrez et al. 2017; de Almeida Alves-Júnior et al. 2019). One species (Oculophryxus bicaulis Shields \& Gómez-Gutiérrez 1996) uses modified antennae to attach to the eyestalk peduncle of euphausiid hosts, whereas species of Heterophryxus G. O. Sars, 1885 also attach to eyestalks but do so with their fifth pereopods. However, species of Heterophryxus and Oculophryxus Shields \& Gómez-Gutiérrez 1996 retain the dorsoventrally flattened typical dajid form as adult females and are closely applied to the host body. Aegophila socialis Bresciani, 1966 is the sole dajid as well as epicaridean known to parasitize the pereopods of its host, a species of aegid isopod; the body of females is more flattened than is typical of other dajids but is otherwise quite similar. Notophryxus lateralis G. O. Sars, 1885 , is found attached to an appendage, either the endopod of the sixth pereopod or the sixth gill (G. O. Sars 1885; Field 1969; Gómez-Gutiérrez et al. 2017) but this species is in a very protected position on the ventral surface of its host.

Herein, we report on two new species of dajids that exhibit an unusual spheroid morphology and novel attachment position partially surrounding the antennules of their decapod hosts. In contrast to the highly modified female morphology, the males, epicaridium and cryptoniscus larvae of these species are typical of dajids in gross morphological details. One species was collected from the western Indian Ocean off Madagascar in nearly $1000 \mathrm{~m}$ depth, whereas the other was obtained in exceptionally deep $(c .5000 \mathrm{~m})$ waters from the southern Caribbean. We also describe a third species of dajid, a new species of the genus Aegophila Bresciani, 1966 from the Bering Sea, found attached to a pereopod of an aegid isopod host. Although the morphology of females of this species is atypical of dajids and apparently specialized for attachment to the legs of hosts, females of this species do not exhibit the spheroid shape found in females of the two new genera attached to host antennules. The present study thus expands our knowledge of the morphological diversity and host attachment strategies within Dajidae, as well as parasitic isopods in general.

\section{MATERIAL AND METHODS}

Methods of specimen collection are indicated in the "Type Material" sections below; data on collections (e.g. longitude and latitude coordinates, depth) are provided from the original records where possible. Carapace length $(\mathrm{CL})$ of hosts was measured from the anterior end of the rostrum to the posterior edge of the carapace and carapace width $(\mathrm{CW})$ was measured as the maximum width of carapace, using calipers. Isopod parasite size is given as maximal diameter for females of the two new genera (Akrophryxus n. gen. and Telephryxus n. gen.) and maximal length for all males and females of Aegophila (from anterior border of cephalon to terminus of uropods). All measurements were made with a micro-scale tool, ocular micrometer, or from drawing tube sketches.

Line drawings of parasites were made by sketching specimens using drawing tubes attached to Olympus compound and dissecting microscopes and using Adobe Illustrator to trace original sketches and produce final figures. Light micrographs were created with a Macropod Pro kit (MacroscopicSolutions) and resulting pictures were aligned and stacked with the focus 
stacking software Zerene Stacker (10-65 images from bottom to top of specimens). For Scanning Electron Microscopy (SEM) preparation of epicaridium larvae, specimens were dehydrated in an ascending ethanol $(\mathrm{EtOH})$ series, starting with $70 \% \mathrm{EtOH}$ and ending with $100 \% \mathrm{EtOH}$. Specimens were then dried in a Samdri 795 Critical Point Dryer, mounted on aluminum stubs, coated with gold using an EMS-550 Sputter coater, and viewed with a FEI Quanta 250 SEM.

All specimens were deposited in the Museum National d'Histoire Naturelle, Paris, (MNHN) and National Museum of Natural History, Smithsonian Institution, Washington D.C., (USNM). References are provided for taxonomic authorities of parasite taxa but not for those of hosts.

\section{SYSTEMATICS}

Family Dajidae G. O. Sars, 1883

Genus Aegophila Bresciani, 1966

Type SPeCIES. - Aegophila socialis Bresciani, 1966

\section{Aegophila cappa n. sp.}

(Figs $1 ; 2$ )

\section{urn:Isid:zoobank.org:act:4FF870BA-A6D1-4A86-87AE-84160A0EA65F}

“parasite” - Richardson 1909: 125, figs 49, 50.

"eine Form ohne Namen auf dem Isopode Aega symmetrica vom Behring-Meer” - Nierstrasz \& Brender à Brandis 1931: 220.

“Aegophila socialis sp. nov.?” - Bresciani 1966: 108-109, fig. 6 (after Richardson 1909) (not $A$. socialis Bresciani, 1966).

Type MATERIAL. - Holotype. Bering Sea • USNM 39524; ovigerous female (3.4 mm W, $2.4 \mathrm{~mm} \mathrm{~L}$ ); attached to pereopod of Aegiochus symmetricus (Richardson, 1905) (USNM 39293); Sta. 4772; 5430'30”N, 179¹4’E; "Bowers Bank"; 344-372 fathoms (= 629$680 \mathrm{~m}$ ); coll. United States Bureau of Fisheries steamer Albatross, taken by 12-foot Tanner beam trawl (Anonymous 1907); 4.VI.1906. Allotype. Bering Sea • USNM 1616634; mature male $(920 \mu \mathrm{m} \mathrm{L})$; same data as for holotype.

Type LOCALITY. - 54³0’30”N, 179¹4’E, “Bowers Bank”, Bering Sea, 629-680 m.

TYPE HOST. - Aegiochus symmetrica (Richardson, 1905) [Crustacea: Isopoda: Aegidae] (originally as Aega symmetrica in Richardson, 1909; see WoRMS 2008b onwards).

ETymology. - The species name is derived from the Latin for cloak or cape $(c a p p a)$, in reference to the fused oostegite 5 and lateral body wall of the female's resemblance to a cloak drawn around the body. The gender is feminine.

DisTRIBUTION. - Known only from the type locality and type host.

\section{DESCRIPTION}

Female

Body (Fig. 1A, B) semicircular, approximately 1.25 times as wide as maximum length, dorsoventrally flattened, with pair of broad lateral lamellae filled with numerous embryos; lateral lamellae not reaching beyond frontal margin of cephalon. Cephalon (Fig. 1A-C) indistinctly dorsally separated from pleon, without eyes. Antennules and antennae apparently absent. Oral cone (Fig. 1B, D) with flaring rounded mandibles, extended, distal surface covered with scale-like structures; posterior margin of oral cone with two finger-like projections. Maxillipeds subquadrate (Fig. 1E). Pereon with few faint transverse and longitudinal folds in cuticle (Fig. 1A). Pereopods 1-5 subequal in size and shape, without setae (Fig. 2F-I, $\mathrm{K}$ ); dactylus short but highly recurved, propodus and carpus fused, carpus expanded into cup receiving tip of dactylus, basis elongate. Oostegite 1 ovate, expanded, few small setae on posterior margin (Fig. $1 \mathrm{H}$ ); oostegite 2 slender, rounded at narrowed distal tip, fringe of setae on proximoventral margin (Fig. 1I); oostegite 3 broader than 2, fringe of thick setae on proximoventral margin (Fig. 1J); oostegite 4 subquadrate, fringe of thick setae on proximoventral margin (Fig. $1 \mathrm{~K}$ ); oostegite 5 fused with lateral pleon, medioventral area with region of setae and small, rounded lobe (Fig. 1B, L). Pleon segments fused, minute, vermiform, without lateral plates or pleopods (Fig. 1B).

\section{Male}

Body not recurved ventrally (Fig. 2A). Cephalon wider than long (Fig. 2A, B), fused with pereomere 1, anterior margin rounded, posterolateral margins (pereomere 1) as small, rounded lobes; lacking eyes, cephalic slits present. Antennules each as single flattened lobe with five or six long setae on medial and distal margins (Fig. 2B, C). Antennae of three segments each with single distal thin flagellum (Fig. 2B, C). Oral cone triangular (Fig. 2B, C). Pereomeres 2-7 distinct, 4-6 subequal in width, others narrower (Fig. 3B); lateral margins of pereomeres 2-7 extended ventrally, with multiple thin setae on margins (Fig. 2B, E). Pereopods with all segments distinct; 1, 2 each with recurved dactylus approximately as long as rounded propodus (Fig. 2B-D), 3-7 with recurved dactylus approximately $25 \%$ as long as slender elongate propodus (Fig. 2E); all ischia and bases elongate. Pleon elongate, subtriangular, segments fused but faint indication of pleomere 1 by rounded lobes and presence of lateral setae similar to those on pereomeres 2-7 (Fig. 2A, B); pleon tapering posteriorly with small distal rounded protrusion bearing terminal setae surrounding anal slit (Fig. 2A, B); pleopods lacking.

\section{REMARKS}

The new species is clearly conspecific with Aegophila socialis; females of both species show dorsoventral compression of the body, lack of antennules and antennae, expanded, clublike mandibles, the same arrangement of oostegites 1-4, the presence of a rounded knob and fringe of thin papillae on the mediovental margin of oostegite 5 , as well as fusion of the fifth oostegites with the ventral body wall, and the pleon being a small, unsegmented protuberance. Males of the two species are similar in having fusion of the cephalon with the first pereomere and presence of rounded posterolateral lobes 


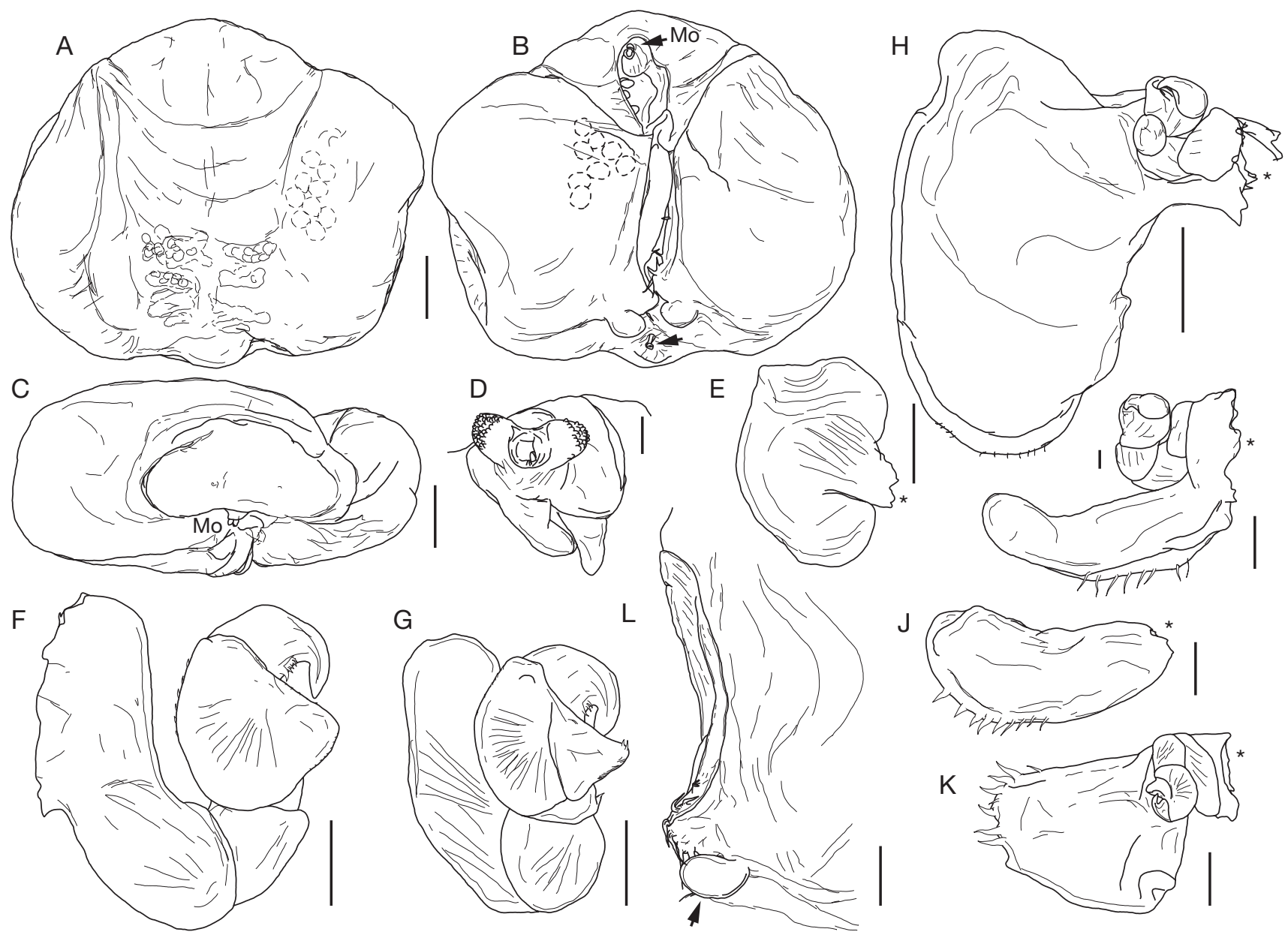

FIG. 1. - Aegophila cappa n. sp., holotype female, USNM 39524: A, dorsal view; B, ventral view (showing mouthparts, Mo; arrow indicates pleon); C, anterior end, en-face (showing mouthparts, Mo); D, mouthparts; E, left maxilliped, outer view; F, left pereopod 3; G, left pereopod 4; H, left oostegite 1 and pereopod 1; I, left oostegite 2 and pereopod 2; J, left oostegite 3 ; $\mathbf{K}$, left oostegite 4 and pereopod 4 ; L, left oostegite 5 , external view of medial edge and posterior end with rounded lobe (arrow). In figures $\mathrm{E}$ and $\mathrm{H}-\mathrm{K}$ asterisks show site of attachment for structures dissected from body of parasite. Scale bars: A-C, 500 $\mu$; $\mathrm{D}$, F, $\mathrm{G}, 50 \mu \mathrm{m} ; \mathrm{E}, \mathrm{H}, \mathrm{L}, 250 \mu \mathrm{m} ; \mathrm{I}-\mathrm{K}, 125 \mu \mathrm{m}$.

corresponding to the side of pereomere 1 , the antennules as unsegmented flaps fringed by setae, and the pleon with all segments fused and lacking pleopods.

Diagnostic differences between females of the two species include: oostegite 1 large, ovate in $A$. cappa n. sp. (small, "spoon-like" in $A$. socialis), oostegite 2 narrow in $A$. cappa n. sp. (broad in $A$. socialis), and oostegite 4 subquadrate in A. cappa n. sp. (ovate in A. socialis). Bresciani (1966) described $A$. socialis as lacking maxillipeds, but they are clearly present in $A$. cappa n. sp. and it is unclear if he overlooked them or if they are truly lacking in $A$. socialis; the latter appears unlikely since maxillipeds are required for oxygenation of the brood (Gilson 1909; Cericola \& Williams 2015). Bresciani (1966) described the pereopods of A. socialis as "small and badly segmented, and do not show any special characters" but did not illustrate them well. In A. cappa n. sp., the pereopods have highly recurved dactyli and show fusion only of the propodus and carpus, with the carpus inner margin being expanded as a cup for insertion of the dactylus.
The males of the two species differ in the form of the antennae (multisegmented with a single flagellum in $A$. cappa n. sp. vs a single segment with a single flagellum in $A$. socialis) and the shape of the pleon (much longer than wide in A. cappa n. sp. vs length and width subequal in $A$. socialis). Bresciani (1966) did not describe the pereopods in detail but did illustrate them. His illustrations appear to show a difference in pereopods 1 and 2 (rounded propodus with typically recurved dactylus) vs 3-7 (elongate propodus and highly recurved dactylus) that is also seen in A. cappa n. sp. However, he drew pereopod 1 as having the propodus and carpus fused whereas in $A$. cappa n. sp., they are distinct.

It is not clear which specimen of Aegiochus symmetrica was the host of $A$. cappa n. sp. as all the of the potential host aegids collected at the parasite's type locality (Sta. 4772, USNM 39293) have their legs intact and no evidence of damage is visible; however, a label reading " 1 sent to W. W. Alpator / Jan 1923" is present in the jar and it is possible that this gifted specimen was the (now lost) host specimen of the holotype of $A$. cappa n. sp. 

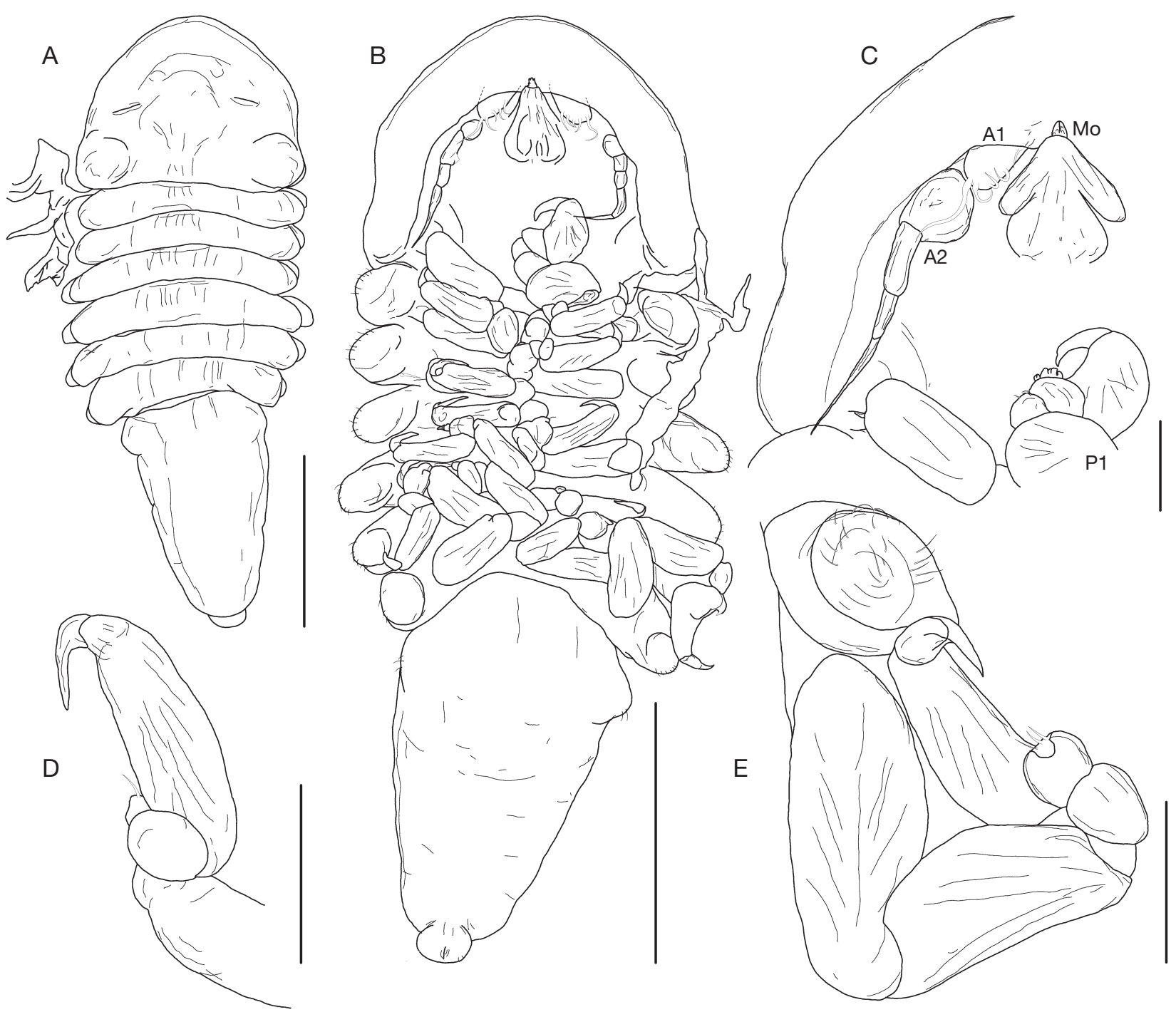

FIG. 2. - Aegophila cappa n. sp., allotype male, USNM 1616634: A, dorsal view; B, ventral view; C, right antennule (A1), antenna (A2), mouthparts (Mo) and pereopod 1 (P1); D, pereopod 2; E, pereopod 7 and side of pereomere 7 . Scale bars: A, B, $250 \mu \mathrm{m} ; \mathrm{C}-\mathrm{E}, 50 \mu \mathrm{m}$.

Genus Akrophryxus n. gen.

urn:Isid:zoobank.org:act:223FBBB0-B294-4C38-ADEA-37C5E561BCB0

TyPE SPECIES. - Akrophryxus milvus n. sp.

ETYMOLOGY. - The genus name is derived from the Greek prefix ákро- (ákro-), meaning "limb" or "extremity" in reference to the specialization of the female of the species on the antennule of the host crab rather than on the host body, in combination with -phryxus,

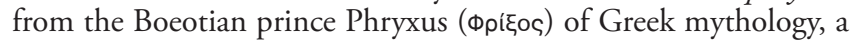
common ending for dajid, as well as some bopyrid, genera. The gender is masculine.

INCLUDED SPECIES. - Akrophryxus milvus n. sp. (type species).

DiAgNosis. - Female. Body spheroid; cephalon externally indistinguishable from pereon. Antennules absent, antennae each as oblong flat plate lateral to oral cone. Maxillipeds ovate with recurved digitiform extension. Pereopods 1-5 subequal in size and shape. Oostegite 1 largest, broadly ovate with small posterior accessory lobe; oostegites $2 / 3,4,5$ progressively larger; oostegite 2 thin and closely applied to oostegite 3 . Pleon apparently modified as oblong, narrow, thickened plate with three circular medial holes: largest surrounding antennule of host, smallest hole at midpoint of plate, intermediate sized hole farthest from mouthparts of parasite.

Male. Cephalon fused with pereomere 1; cephalic slits present. Antennules of three stacked discs, flagella absent; antennae broad elongate lobes lateral to oral cone, flagella absent. Pereomeres 2-6 distinct; pereomere 7 fused with pleon, lateral margins recurved ventrally. Pereopods 1-6 subequal in size and shape; pereopod 7 lacking. Pleon rounded, all segments fused and fused with pereomere 7; pleopods lacking.

\section{REMARKS}

See Remarks below under Akrophryxus milvus n. gen., n. sp. for comparison of female and male characters of Akrophryxus n. gen., Telephryxus n. gen., and other dajid genera. 


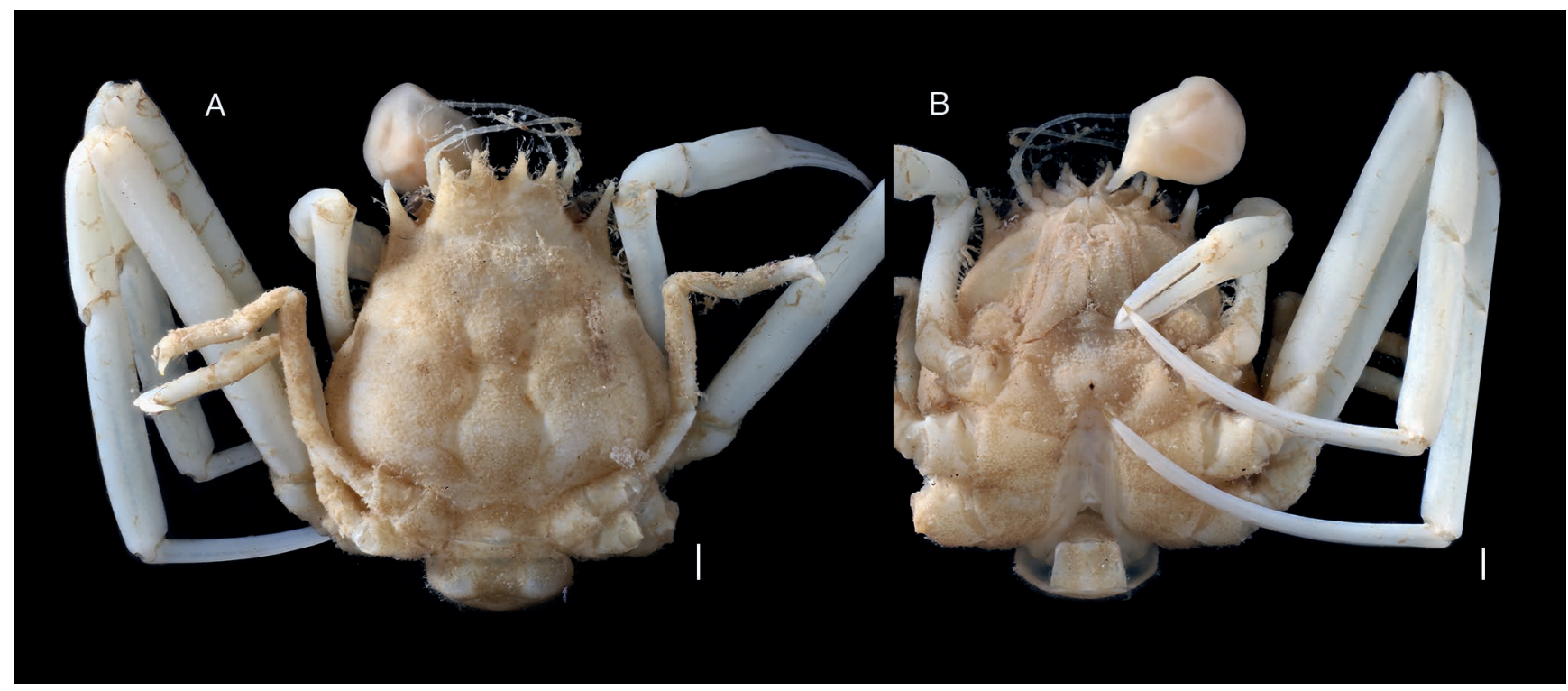

FIG. 3. - Akrophryxus milvus n. gen., n. sp., holotype female, MNHN-IU-2014-20314, attached to Ethusa machaera Castro, 2005, macropod images: A, dorsal view of host, showing parasite attached to left antennule; B, ventral view of host, lateral view of parasite showing attachment to left antennule. Scale bars: A, B: $1 \mathrm{~mm}$.

\section{Akrophryxus milvus n. sp.}

(Figs 3-5, 11Q, R)

\section{urn:Isid:zoobank.org:act:AC0E5AFB-69BB-434D-86A6-A679F9EACDBC}

"sacculinid (? parasite attached to antennular fossa)" - Castro 2013: 443.

TYPE MATERIAL. — Holotype. Madagascar • MNHN-IU-2014-20314; ovigerous female ( $3.1 \mathrm{~mm}$ diameter), attached to left antennule of male Ethusa machaera Castro, 2005 (9.2 mm CL, $9.0 \mathrm{~mm}$ CW; MNHN-IU-2010-1997); Sta. CP 3595; 25³5'28.2012”S,

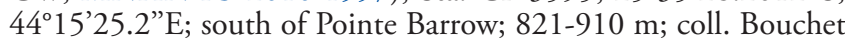
et al. on the shrimper Nosy Be 11; ATIMO VATAE expedition, collected by trawling; 12.V.2010.

Allotype. Madagascar • MNHN-IU-2014-20315; mature male (740 $\mu \mathrm{m} \mathrm{L)}$; same data as for holotype.

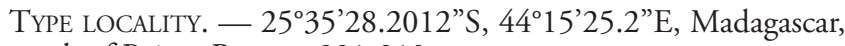
south of Pointe Barrow, 821-910 m.

TYPE HOST. - Ethusa machaera Castro, 2005 [Crustacea: Brachyura: Ethusidae].

ETYMOLOGY. - The species name is derived from the Latin for "kite" in reference to the plate partially surrounding the host antennule that is reminiscent of the shape of a kite shield, defensive armor used primarily in Western Europe in the 10th-13th centuries. The gender is masculine.

DistRiBUTION. - Known only from the type locality and type host.

\section{DESCRIPTION}

Female

Body spheroid, length and width nearly equal, filled with numerous eggs (Figs 3A, B; 4A, C-G). Cephalon externally indistinguishable from pereon, without eyes. Antennules absent, antennae each as oblong flat plate lateral to oral cone, covered with minute scales (not shown) (Figs 4G; 5G). Oral cone rounded (Fig. 4G); mouthparts indistinct. Maxillipeds ovate with recurved digitiform extension (Fig. $5 \mathrm{H}$ ). Pereopods 1-5 subequal in size and shape, without setae (Figs 4G; $5 \mathrm{E}, \mathrm{F})$; dactylus short, recurved, propodus carpus and merus fused, ischia and bases stout. Oostegite 1 largest (Figs 4G; 5J), broadly ovate with small posterior accessory lobe, broad lobe medially divided in lateral view (Fig. $5 \mathrm{~K}$ ); oostegites $2 / 3,4,5$ progressively larger; oostegite 2 present, thin and closely applied to oostegite 3 , lobes subequal in size and shape (Fig. 5L); oostegite 3 subtriangular (Fig. 5L), expanded posteriorly, medial and anterior finger-like extensions present with small setae distally, oostegites 4 and 5 subquadrate, small setae on medial and posterior margins (Fig. 5M). Pleon presumably modified (see Discussion) as oblong, narrow, thickened plate (Fig. 4A-G) partially surrounding host antennule with three circular medial holes: largest surrounding antennule of host and closest to mouthparts of parasite, smallest hole at midpoint of plate, intermediate sized hole farthest from mouthparts of parasite.

\section{Male}

Body not recurved ventrally (Fig. 5A, B). Cephalon fused with pereomere 1 (Fig. 5A, B), anterior margin rounded, posterolateral margins evenly rounded; lacking eyes, cephalic slits present. Antennules reduced, each apparently composed of three flattened disc-shaped segments (Fig. 5C); antennae each as single broad elongate lobes lateral to oral cone, flagella absent (Fig. 5C). Oral cone triangular (Fig. 5B, C). Pereomeres 2-6 distinct, 4-6 subequal in width, others slightly narrower (Fig. 5A, B); pereomere 7 fused with pleon, lateral margins recurved ventrally. Pereopods 1-6 subequal in size and shape, all segments distinct, carpi rounded, ischia short, bases elongate; dactylus, propodus and carpus with isolated marginal setae (Fig. 5B-D); pereopod 7 lacking. Pleon com- 


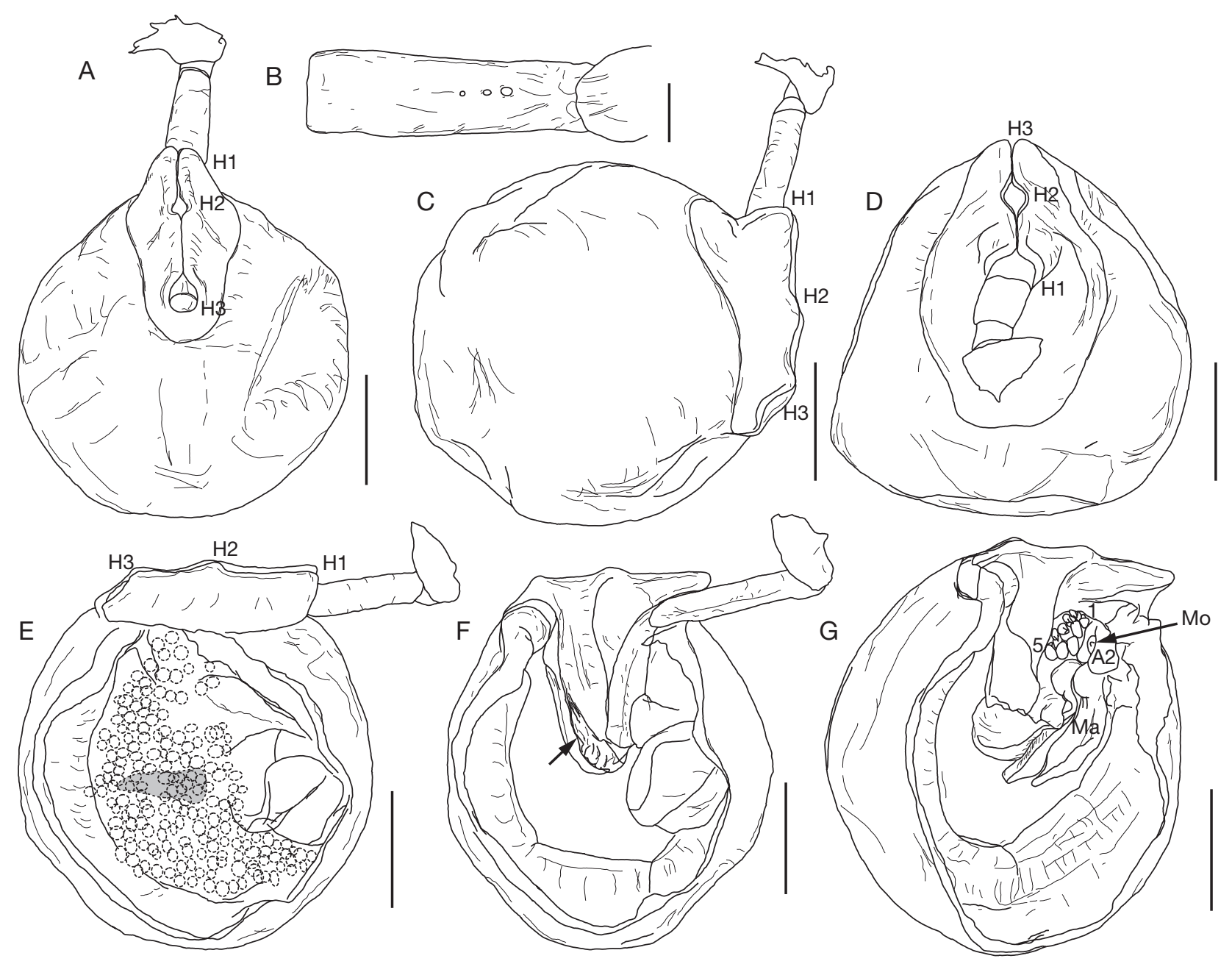

FIG. 4. - Akrophryxus milvus n. gen., n. sp., holotype female, MNHN-IU-2014-20314: A, posterior view, proximal end of host antenna extending from body of parasite at top; $\mathbf{B}$, host antennule, middle segment showing attachment sight of parasite with three holes created by mouthparts; $\mathbf{C}$, lateral view, left side showing proximal end of host antenna extending from body of parasite; $\mathbf{D}$, anterior view (opposite side to that shown in $\mathbf{A}$; proximal end of host antenna facing viewer); $\mathbf{E}$, lateral view, right side, outer membrane of parasite removed showing brood of developing eggs (dashed circles) and position of male shown by grey outline; $\mathbf{F}$, lateral view, right side with eggs removed and showing position of host antenna (arrow indicates distal end); G, lateral view, right side with host antenna and eggs removed showing mouthparts (Mo), antenna (A2), maxilliped (Ma) and pereopods (1 and 5 labeled). In figures A, C, D, and E, the three circular medial holes in pleon are labeled (hole surrounding antennule of host and closest to mouthparts, H1; hole at midpoint, H2; hole farthest from mouthparts, H3). Scale bars: A, C-G, $1 \mathrm{~mm}$; B, $250 \mu \mathrm{m}$.

pact, rounded, all segments fused and fused with pereomere 7 , rounded posteriorly; anal slit and pleopods lacking (Fig. 5A, B).

\section{REMARKS}

The female of Akrophryxus milvus n. gen., n. sp. is very different from those in all other dajids, excepting Telephryxus clypeus n. gen., n. sp. (Table 1). The spheroid shape of the body and possession of a plate partially surrounding the host antennule are shared only by these two genera. The male of A. milvus n. gen., n. sp. is likewise very different from those in all other dajid genera (Table 2), including T. clypeus n. gen., n. sp. in having only six pairs of pereopods with no trace of the seventh pair (pereopod 7 of two elongate segments in the sole species of Oculophryxus and of one or two stub-like segments in T. clypeus n. gen., n. sp.). The male of $A$. milvus n. gen., n. sp. also differs from those in most genera in having the pleon fused with pereomere 7 (distinct from pereomere 7 in males in all other genera except Holophryxus Richardson, 1905 and Oculophryxus), and from all other genera in having a reduced antennule and an antenna with a single large segment (males of other genera with antennules of at least one well-developed segment and all with antennae segmented and with distal flagella).

The female of $A$. milvus n. gen., n. sp. can be distinguished from that of T. clypeus n. gen., n. sp. in lacking antennules and in having three medial holes on the narrow, triangular attachment plate partially surrounding the host antennule with no additional lateral holes (T. clypeus n. gen., n. sp. has flattened antennules and a broad, subquadrate attachment plate partially surrounding the host antennule and having two large medial holes, the largest with two additional small lateral holes). The male of $A$. milvus n. gen., n. sp. can be distinguished from that of T. clypeus n. gen., n. sp. in having only six pairs of pereopods (six fully-developed pairs plus a rudimentary seventh pair of one 

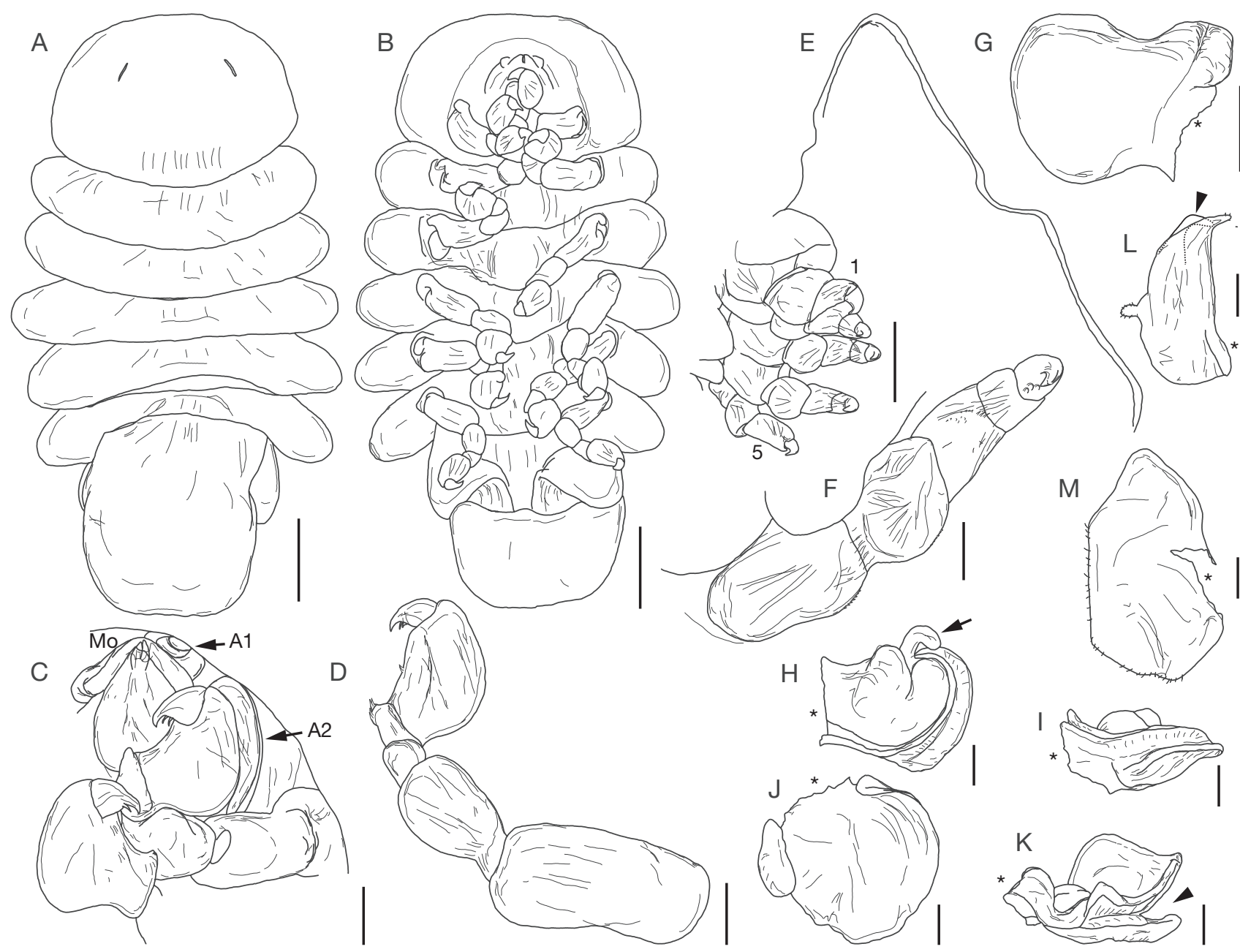

FIG. 5. - Akrophryxus milvus n. gen., n. sp., allotype male (A-D; MNHN-IU-2014-20315) and holotype female (E-M; MNHN-IU-2014-20314): A, dorsal view; B, ventral view; C, ventral view of anterior end showing left antennule (A1), left antenna (A2), mouthparts (Mo) and first pereopods; $\mathbf{D}$, right pereopod 6; E, pereopods 1-5 from left side (1 and 5 labeled with numbers); $\mathbf{F}$, pereopod 3 from left side; $\mathbf{G}$, antenna from left side, covered in scales (not shown); $\mathbf{H}$, left maxilliped, ventral view, arrow shows digitiform extension that is inserted in fold of oostegite 1 in part $\mathbf{K}$ (shown by arrowhead); I, left maxilliped, lateral view; J, left oostegite 1, ventral view; K, left oostegite 1, lateral view showing fold where digitiform extension of maxilliped resides (arrowhead); L, left oostegite 3, anterior portion of oostegite 2 shown by arrowhead and in dashed line; $\mathbf{M}$, left oostegite 5 . In Figures $2 \mathrm{G}, \mathrm{H}-\mathrm{K}$, and $\mathrm{M}$ asterisks show site of attachment for structures dissected from body of parasite. Scale bars: A, B, G, L, M, $100 \mu \mathrm{m}$; C, D, $25 \mu \mathrm{m} ; \mathrm{E}, \mathrm{H}-\mathrm{K}, 250 \mu \mathrm{m} ; \mathrm{F}, 50 \mu \mathrm{m}$.

or two small segments in T. clypeus n. gen., n. sp.), a reduced antennule and a single segmented antenna (large ovate single segmented antennule and two segmented short antennae in T. clypeus n. gen., n. sp.), and the short and rounded pleon fused to pereomere 7 (pleon distinct from pereomere 7 , elongate and tapered pleon in T. clypeus n. gen., n. sp.).

\section{Genus Telephryxus n. gen.}

urn:Isid:zoobank.org:act:A2832732-89F2-4D20-A01D-D7ACC4D4D909

TyPe SPECIES. - Telephryxus clypeus n. sp.

ETYMology. - The genus name is derived from the Greek prefix $\tau \tilde{\eta} \lambda \varepsilon$ - (tele-), meaning "far away" in reference to the specialization of the female of the species on the antennule of the host crab rather than on the host body (as in "far away from the host's body") as well as to the occurrence of the sole species in the abyssopelagic zone (far away from the habitat of most dajids), in combination

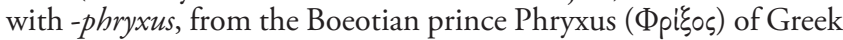
mythology, a common ending for dajid, as well as some bopyrid, genera. The gender is masculine.

InCLUded SpeCiEs. - Telephryxus clypeus n. sp. (type species).

DiAgNosis. - Female. Body spheroid; cephalon externally indistinguishable from pereon. Antennules each as flat triangular plate; antennae each as flat rectangular plate lateral to oral cone. Maxillipeds inflated, rectangular, each with recurved maxilliped digitiform extension ("appendix") at posterolateral corner. Pereopods 1-5 subequal in size and shape. Oostegite 1 largest, broadly ovate with large triangular posterior accessory lobe; oostegites 2-4 flat, ovate; oostegite 5 flat, tapering. Pleon apparently modified as subquadrate, broad, thickened plate with two circular medial holes, subequal in size; hole surrounding distal portion of host antennular peduncle with one small additional hole on each lateral margin. 
Male. Cephalon fused with pereomere 1; cephalic slits present. Antennules each as single ovate plate lateral to and extending posterior to oral cone; antennae of two segments each, flagella absent. Pereomeres 2-7 distinct, lateral margins recurved ventrally. Pereopods 1-6 subequal in size and shape; pereopod 7 reduced, single rounded stub on right side, rounded stub plus dactylus on left side. Pleon tapering to rounded tip, all segments fused, distinct from pereomere 7; pleopods lacking. Cryptoniscus larva: Body tear-drop shaped. Cephalon medial region of posterior margin convex, lateral regions concave, posterolateral margins extended posteriorly. Antennules of three articles each, basal article triangular, article 2 quadrate, article 3 digitiform, inserted into article 2 distoventrally. Antennae of nine articles each, peduncular articles subequal in size; flagellar articles approximately half width of peduncular articles. Oral cone lacking oral sucker (possible artifact due to loss during collection). Pereomeres 1-7 with entire coxal plates. Pereopod 1 with short, slightly curved dactylus, propodus semi-spherical; pereopods 2-6 with more elongate curved dactyli, propodi progressively more elongate. Pereopod 7 with long, slightly curved dactylus, propodus elongate with two large multifid setae near base of dactylus; carpus with distal large multifid seta; merus triangular with anterodorsal edge extending into spine-like extension, ischium triangular, basis cylindrical. Pleon with five pairs of biramous pleopods, endopods cylindrical, exopods triangular. Pleotelson oval. Uropods biramous, sympod broad, endopod slightly longer than exopod.

\section{REMARKS}

See Remarks above under Akrophryxus milvus n. gen., n. sp. for comparison of female and male characters of Akrophryxus n. gen., Telephryxus n. gen., and other dajid genera.

\section{Telephryxus clypeus n. sp.} (Figs 6-10;11N)

\section{urn:Isid:zoobank.org:act:B21DCDDB-9E3D-4380-A7E8-C0968B50C99C}

“remarkable isopod parasite (Dajidae?)” - Gore 1983: 207.

Type Material. - Holotype. Caribbean Sea • USNM 1163461; female ( $8.0 \mathrm{~mm}$ diameter) with pre-molt epicaridean larvae, attached to right antennule of female Munidopsis crassa Smith, $1885(40.9 \mathrm{~mm}$ CL, incl. rostrum; USNM 204595); NORDA Sta. 99; $14^{\circ} 51.70^{\prime} \mathrm{N}$ 67²7.8’W; Venezuela Basin, north of Islas de Aves; 4956-4997 m; coll. United States Navy research vessel USNS Bartlett, taken by $45 \mathrm{ft}$ balloon net trawl (Gore 1983); 3.XII.1981.

Allotype. Caribbean Sea • USNM 11616635; mature male $(2.4 \mathrm{~mm}$ L); same data as for holotype.

Paratype. Caribbean Sea • USNM 11616636; cryptoniscus larva $(0.9 \mathrm{~mm} \mathrm{~L})$; same data as for holotype.

AdDitional MATERIAL. — USNM 11616637, c. 30 pre-molt epicaridium larvae, same data as for holotype (on SEM stubs).

TyPe LOCALITY. $-14^{\circ} 51.70^{\prime} \mathrm{N}, 67^{\circ} 27.8^{\prime} \mathrm{W}$, Venezuela Basin, Caribbean Sea, 4956-4997 m (fide Gore, 1983).

TYPE HOST. - Munidopsis crassa Smith, 1885 [Crustacea: Anomura: Munidopsidae].

Etymology. - The species name is derived from the Latin for "shield" in reference to the broad subquadrate plate that partially surrounds the host antennule and is reminiscent of the shape of a shield. The gender is masculine.

Distribution. - Known only from the type locality and type host.

\section{DESCRIPTION}

Female

Body spheroid (Figs 6; 7A, B), length and width nearly equal, filled with numerous pre-molt epicaridium larvae (see description below). Cephalon externally indistinguishable from pereon, without eyes. Antennules (Fig. 7F) each as flat triangular plate covered with minute scales (not shown); antennae each as rectangular flat plate lateral to oral cone (Fig. 7E, G), covered with minute scales (Fig. 7G inset). Oral cone rounded (Fig. 7E); mouthparts indistinct. Maxillipeds inflated, rectangular, each with recurved maxilliped digitiform extension ("appendix") at posterolateral corner (Figs 6E, $7 \mathrm{E}, \mathrm{H}, \mathrm{K})$, "appendix" extending into groove of oostegite 1 (Fig. 7K). Pereopods 1-5 subequal in size and shape, without setae (Fig. 7E); dactylus short, recurved, propodus carpus and merus fused (indistinct ventral indication of segmentation on some pereopods), ischia and bases stout. Oostegite 1 largest, broadly ovate with large triangular posterior accessory lobe (Figs 6E; 7I, J, K), broad rounded lobe medially divided in lateral view, forming groove (Fig. 7J, K); oostegites 2-4 flat, ovate, posterior pairs progressively slightly larger (Fig. $7 \mathrm{~K}$ ); oostegite 5 flat, elongate, tapering, lacking marginal setae (Fig. 5L). Pleon presumably modified (see Discussion) as subquadrate, broad, thickened plate (Figs 6A-D; 7A, B, D) partially surrounding host antennule with two circular medial holes, subequal in size; hole surrounding basal antennular peduncle of host closest to mouthparts of parasite, hole surrounding distal portion of host antennular peduncle with one small additional hole on each lateral margin.

\section{Male}

Body not recurved ventrally (Fig. 8A, B). Cephalon fused with pereomere 1 (Fig. 8A-C), anterior margin subtriangular, posterolateral margins evenly rounded; faint unpigmented eyes, cephalic slits present. Antennules each as single ovate plate lateral to and extending posterior to oral cone, with minute lateral projection bearing terminal setae (Fig. 8C); antennae lateral to antennules, of two segments each with distal setae (Fig. 8C), flagella absent. Oral cone subtriangular (Fig. 8B, C). Pereomeres 2-7 distinct, 2-6 subequal in width, 7 slightly narrower, lateral margins recurved ventrally (Fig. 8A, B). Pereopods 1-6 subequal in size and shape (Fig. 8B-D), ischia and bases fused, carpi rounded, ischia/bases elongate; dactylus and propodus with isolated marginal setae; pereopod 7 reduced, single rounded stub on right side, rounded stub plus dactylus on left side. Pleon elongate (Fig. 8A, B), tapering to rounded tip, all segments fused, distinct from pereomere 7; anal slit and pleopods lacking.

\section{Cryptoniscus larva}

Body tear-drop shaped (Fig. 9A, B), length 0.9 mm, maximum width at pereomere 3. Cephalon anterior margin round, medial region of posterior margin convex, lateral regions concave, posterolateral margins extended posteriorly (Fig. 9A); eyes round, unpigmented. Body pigmentation lacking. Antennules of three articles each (Fig. 9C), basal article triangular with five stout distal setae, article 2 quadrate with four stout distal 


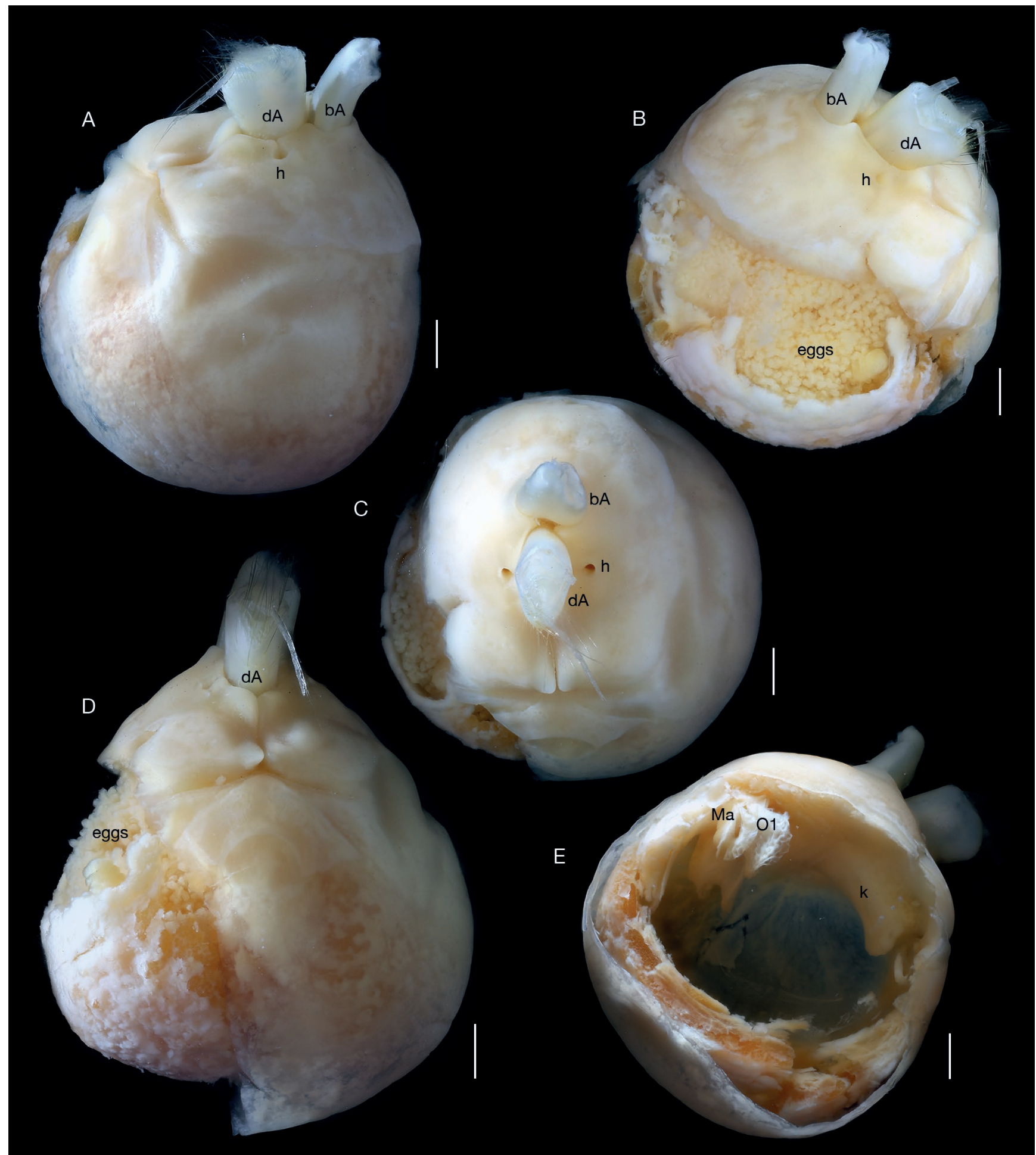

FIG. 6. - Telephryxus clypeus n. gen., n. sp., holotype female, macropod images, USNM 1163461: A, lateral view, right side showing host antennule extending from top (remains of distal end of host antennule to left, basal end of host antennule to right); B, oblique view of left side, outer membrane of parasite removed, showing brood of eggs; $\mathbf{C}$, top down view, showing lateral openings in parasite body to side of host antennule; $\mathbf{D}$, posterior view, membrane of parasite removed on left side, showing brood of eggs; $\mathbf{E}$, lateral view, left side with eggs removed showing maxillipeds (Ma), oostegite 1 (O1) and raised keel-like structure (k) that extends posteriorly. In figures A-D, the basal antennular peduncle of host (bA), distal portion of host antennular peduncle (dA), and small additional hole in pleon (h) are labeled. Scale bars: A-E, $1 \mathrm{~mm}$.

setae and several low, rounded bumps, article 3 digitiform, inserted into article 2 distoventrally, less than half width of article 2, with two distal setae (Fig. 9C). Antennae of nine articles each (four peduncular and five flagellar) (Fig. 9B, D), all articles cylindrical, peduncular articles subequal in size with minute, distal setae (at least on articles 3 and 4); flagellar 


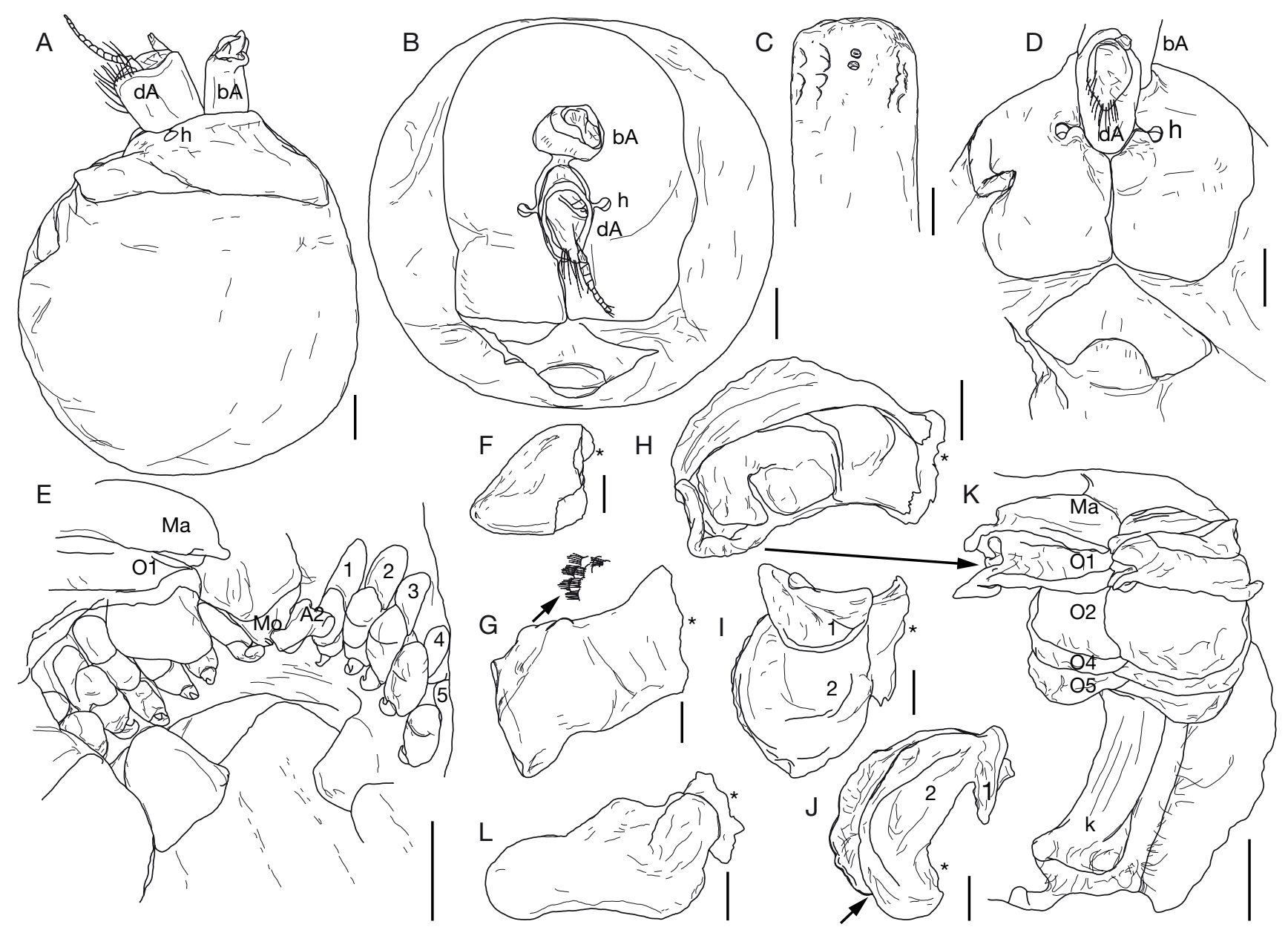

FIG. 7. - Telephryxus clypeus n. gen., n. sp., holotype female, USNM 1163461: A, lateral view, right side showing host antennule extending from top (remains of distal end of host antennule to left, basal end of host antennule to right); B, top down view (remains of distal end of host antennule to top, basal end of host antennule to bottom); C, host antennule showing attachment sight of parasite with two holes created by mouthparts and rows of scars from pereopods; $\mathbf{D}$, posterior view, showing lateral openings in parasite body to side of host antennule; E, ventral view showing showing mouthparts (Mo), antenna (A2), maxilliped (Ma) and pereopods (1-5 labeled); $\mathbf{F}$, antennule; $\mathbf{G}$, antenna, arrow shows magnified view of scales that cover both antennae; H, right maxilliped, arrow shows position of curved digitiform extension and where it is inserted in fold of oostegite 1 in part K; I, right oostegite 1, showing two lobes (1 and 2); J, right oostegite 1, view showing two lobes (1 and 2) and fold along edge within which digitiform extension of maxilliped resides; $\mathbf{K}$, ventral view of body showing maxillipeds (Ma), oostegite 1 (01) and pereopods (1-5 labeled) and raised keel-like structure (k) that extends posteriorly; L, left oostegite 5 . In figures A, B, and $\mathbf{D}$, the basal antennular peduncle of host (bA), distal portion of host antennular peduncle of host (dA), and small additional hole in pleon (h) are labeled. In figures $\mathbf{F}-\mathbf{J}$, and $\mathbf{L}$ asterisks show site of attachment for structures dissected from body of parasite. Scale bars: A, B, D, E, K, $1 \mathrm{~mm} ; \mathrm{C}, \mathrm{H}, \mathrm{I}, \mathrm{J}, \mathrm{L}, 500 \mu \mathrm{m} ; \mathrm{F}, \mathrm{G}, 200 \mu \mathrm{m}$.

articles approximately half width of peduncular articles, with minute terminal setae, distalmost article with two long terminal setae (Fig. 9D). Oral cone triangular, anteriorly directed, lacking oral sucker (see Remarks) (Fig. 9B, E). Pereomeres 1-7 with entire (not toothed) coxal plates (Fig. 9B). Pereopod 1 with short, slightly curved dactylus, propodus semi-spherical with distoventral ridge corresponding to dactylus tip position bearing stout, simple setae; carpus with distal seta; merus and ischium rounded, basis cylindrical (Fig. 9D, E). Pereopods 2-6 with more elongate curved dactyli, propodi progressively more elongate with distoventral ridge corresponding to dactylus tip position bearing stout, simple setae; each carpus with distal seta; meri and ischia rounded, bases cylindrical (Fig. 9E, F). Pereopod 7 with long, slightly curved dactylus, propodus elongate with distoventral ridge corresponding to dactylus tip position, with two large multifid setae and one simple seta near base of dactylus; carpus with distal large multifid seta; merus triangular with anterodorsal edge extending into spine-like extension closely applied to propodus dorsal margin, ischium large, triangular, basis long, cylindrical (Fig. 9G). Pleon with five pairs of biramous pleopods, endopods cylindrical, exopods triangular, both with long terminal setae (Fig. 9H). Pleotelson oval, with rounded distomedial margin (Fig. 9A, I). Uropods biramous, composed of wide sympod with lateral projection and seta, endopod slightly longer than exopod, pair of long distal setae on endopods and exopods, short seta at distolateral margin of endopods and exopods (Fig. 9I).

\section{Pre-Molt Epicaridium Larva}

Length $228.1 \pm 13.7 \mu \mathrm{m}(\mathrm{n}=30)$ from anterior margin of cephalon to end of pleotelson. Body ovoid (Fig. 10A), covered in wrinkled cuticle, obscuring segmentation of append- 

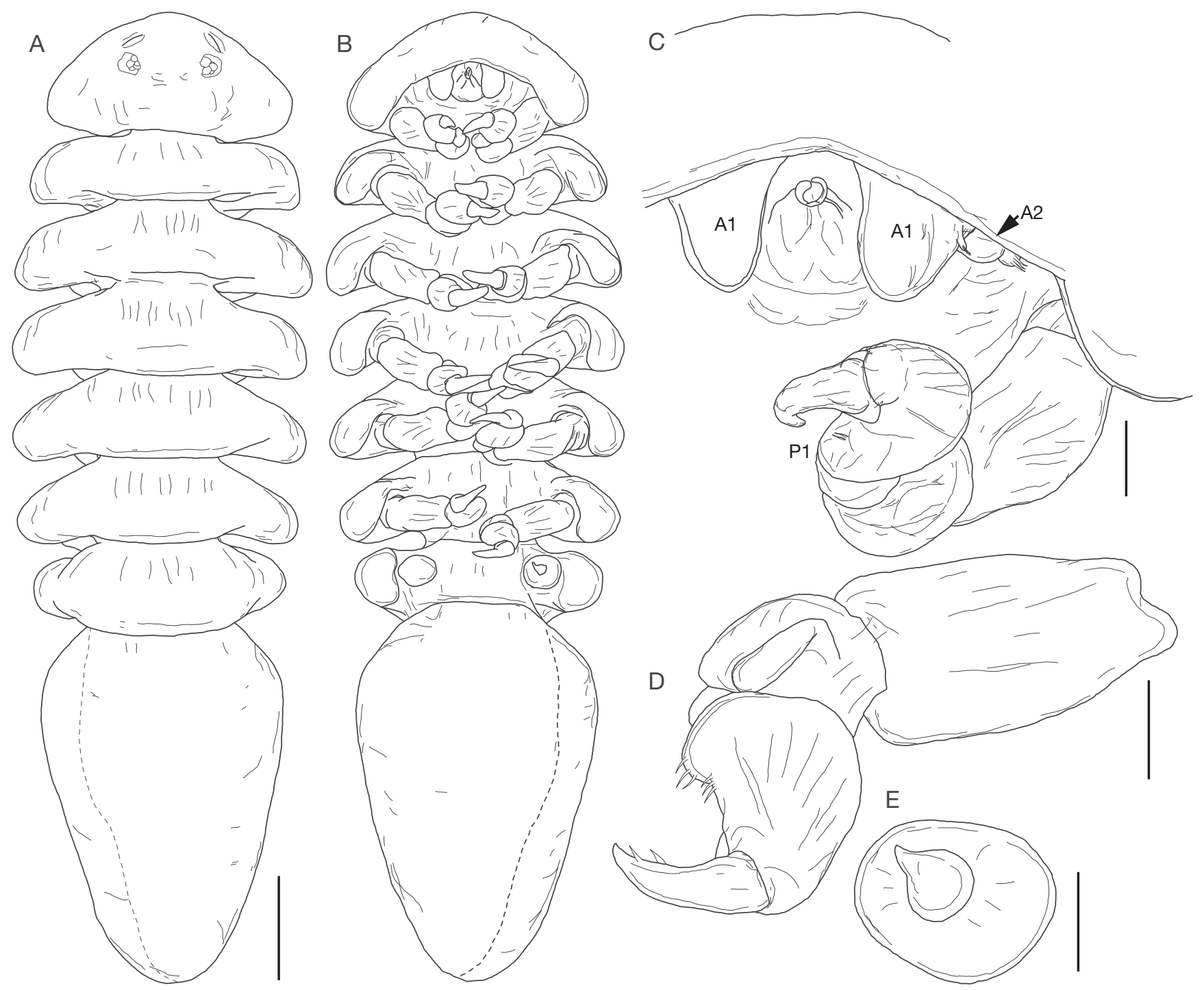

FIG. 8. - Telephryxus clypeus n. gen., n. sp., allotype male, USNM 1616635: A, dorsal view; B, ventral view; C, ventral view of anterior end showing mouthparts, antennules (A1), antenna (A2) and left first pereopod (P1); D, left pereopod 6; E, left pereopod 7. Scale bars: A, B, $250 \mu \mathrm{m}$; C-E, $50 \mu \mathrm{m}$.

ages. Cephalon large, rounded anteriorly; in ventral view, broad and extending laterally, appearing fused with antennules (Fig. 10B, D). Antennule triangular with large basal portion, two distal lobes and additional smaller extensions (Fig. 10B, D F). Antenna long, approximately $3 / 4$ length of body (Fig. 10A, B, E) with small distal lobes (Fig. 10C, G). Oral region inflated, no distinct oral cone, with pair of lobes (maxillipeds) anterior to pair of smaller lobes (Fig. 10B, D). Six pairs of rounded, broadly hooked pereopods, subequal in size, segmentation not visible (Fig. 10B, D, E). In lateral view, sides of pereomeres and pleomeres with thin extensions; anterior pleomeres 3-5 with crenulate margins (Fig. 10E, G). Pleon with 5 pairs of pleopods (Fig. 10B, $\mathrm{C}, \mathrm{G}$ ); pleopods 1-4 biramous, bearing three long terminal setae on each exopod and two long terminal setae on each endopod; pleopod 5 reduced, uniramous, lacking long terminal setae. Uropods biramous, endopods slightly shorter than exopods, both ending in two short lobes, terminal setae lacking (Fig. 10D, G).

\section{REMARKS}

See Remarks under Akrophryxus milvus n. gen., n. sp. for comparison with Telephryxus clypeus n. gen., n. sp. and other dajids. The maxilliped digitiform extension ("appendix" of Rustad 1935) appears homologous with the lateral lobes of the barbula found in bopyrids (Markham 1985). As in bopyrids, the maxillipeds are used to pump water through the brood chamber, oxygenating the eggs or larvae (Gilson 1909; Cericola \& Williams 2015). However, in the case of females of species in the two new genera, the digitiform extension of the maxilliped also fits into the groove of oostegite 1 , thus further aiding in oxygenation by moving the whole first oostegite. It may also aid in maintaining larvae in the brood chamber prior to release (Cericola \& Williams 2015). 

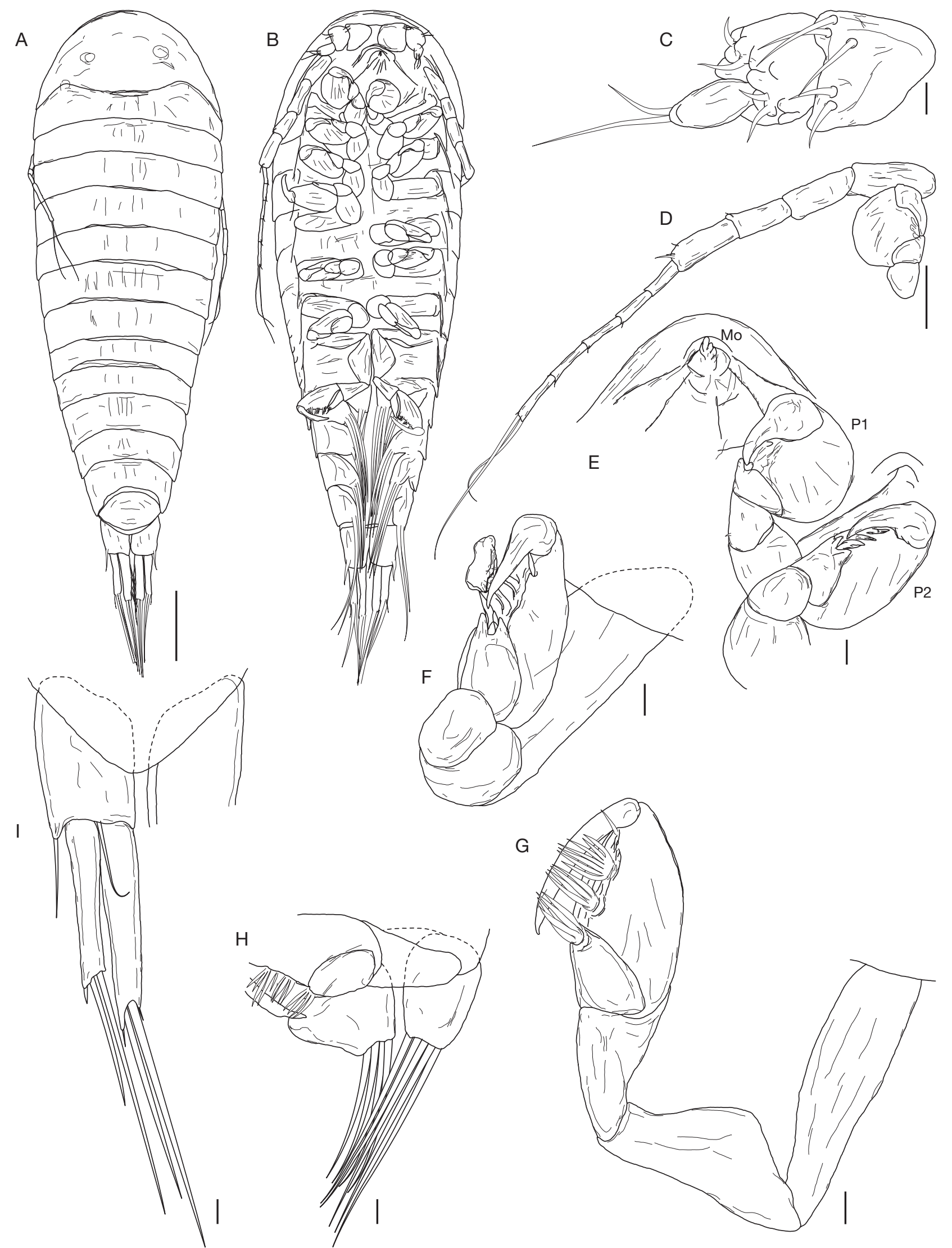

FIG. 9. - Telephryxus clypeus n. gen., n. sp., paratype cryptoniscus larva, USNM 1616636: A, dorsal view; B, ventral view; C, left antennule; D, left antenna and pereopod 1; E, ventral view of mouthparts (Mo), right pereopod $1(\mathbf{P 1})$, right pereopod 2 (P2); $\mathbf{F}$, left pereopod 6; G, left pereopod 7; H, left pleopod 1 and part of left pereopod 7; I, pleotelson and left uropod, dorsal view. Scale bars: A, B, $100 \mu \mathrm{m} ; \mathrm{C}, \mathrm{E}-\mathrm{I}, 10 \mu \mathrm{m} ; \mathrm{D}, 50 \mu \mathrm{m}$. 

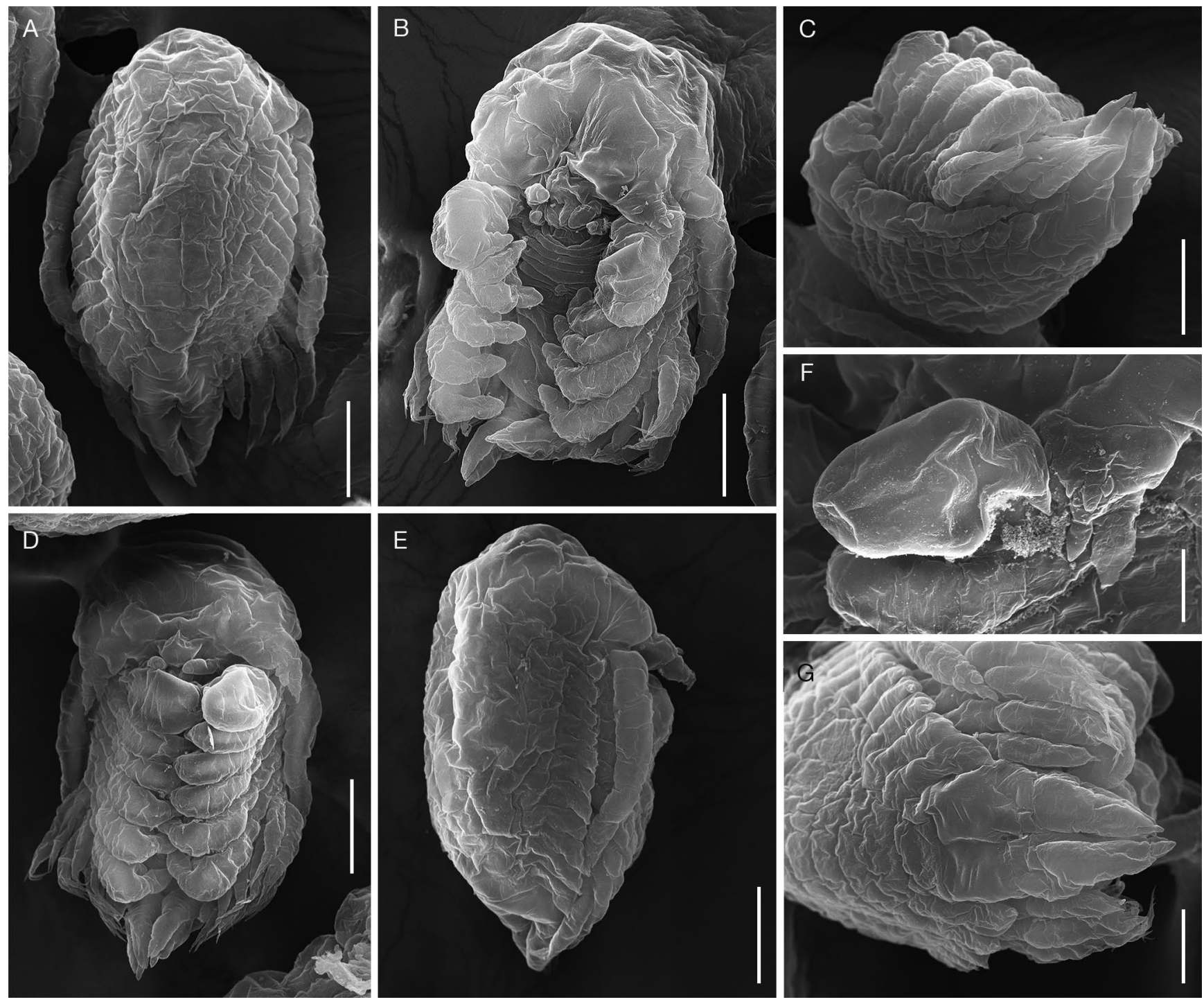

FIG. 10. - Telephryxus clypeus n. gen., n. sp., epicaridium larvae, USNM 1616637: A, dorsal view; B, ventral view; C, oblique, lateral view; D, ventral view; E, lateral view; F, left pereopod 1 and antennule; G, posterior end, dorsal view. Scale bars: A-E, $50 \mu \mathrm{m} ; \mathrm{F}, 15 \mu \mathrm{m} ; \mathrm{G}, 25 \mu \mathrm{m}$.

The epicaridium larvae of Telephryxus clypeus n. gen., n. sp. were in pre-molt, having a wrinkled cuticle (particularly evident surrounding the cephalon, antennae and pereopods) similar to that shown in larvae of other dajid species (G. O. Sars 1898: pl. 94; Gilson 1909: figs 10, 11; Shimomura et al. 2005: fig. 12). As discussed by Gilson (1909), there are two stages of epicaridium larvae: the first is maintained within the brood chamber of the female and the second is released from the female as the planktonic phase prior to attachment to a copepod intermediate host (Fig. 11A-G). In addition to the yolk provisioned endogenously to the epicaridium larvae, they may also be provisioned with exogenous sources of nutrition taken up across the embryonic epithelial layer (as discussed by Strömberg [1971] and shown to occur in cryptoniscoids by Goudeau [1977]) that fuel their final development prior to release into the water column. After molting, the second stage (mature) epicaridium larvae of dajids show distinct segmentation of appendages (e.g. G. O. Sars 1898; Gilson 1909; Tattersal 1911; Taberly 1957a). The pleopods of the epicaridium larvae of T. clypeus $\mathrm{n}$. gen., n. sp. all appear biramous (as they do in other pre-molt larvae previously described; e.g. Stephensen [1913], Shimomura et al. [2005]). However, it is not clear if any or all of these will remain biramous or become uniramous in the mature epicaridium larvae. Pleopods of mature epicaridium larvae of dajids have been described with both uniramous and biramous states: pleopods 1-5 uniramous (Gilson 1909) or pleopods 1-4 biramous and 5 uniramous (Taberly 1957a; Coyle \& Mueller 1981).

The uropods of the pre-molt epicaridium larvae of T. clypeus n. gen., n. sp. are biramous, as are those of the mature epicaridium larvae described by Taberly (1957a). However, the orientation of the endopod and exopod of the uropods is ninety degrees rotated ("superposées" of Trilles 1999) from 


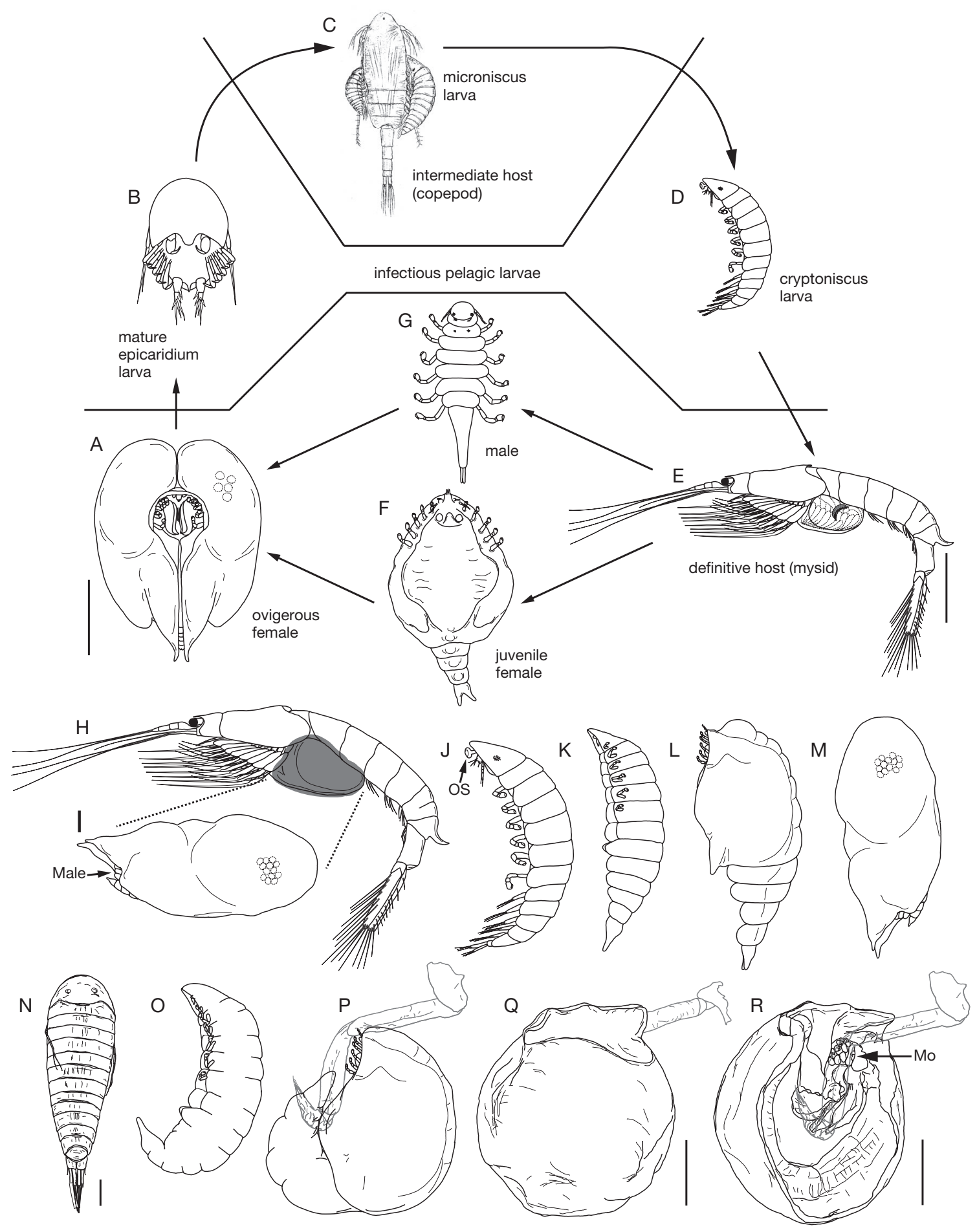

FIG. 11. - Life-cycle diagram of the dajid isopod Prodajus ostendensis Gilson, 1909 parasitizing the opossum shrimp Gastrosaccus spinifer (Goës, 1864): A, ovigerous female, ventral view. Eggs (shown in dashed circles) develop into early epicardium larvae and then molt once; B, mature epicaridium larvae released into the water column; $\mathbf{C}$, mature epicaridium larvae find copepod intermediate host, attach and metamorphose into an ectoparasitic microniscus larva. Microniscus larva transforms into a cryptoniscus larva that detaches and is free-swimming; $\mathbf{D}$, cryptoniscus larva settles on host mysid and invades marsupium; $\mathbf{E}$, within the host marsupium the cryptoniscus larva transforms into a juvenile female; $\mathbf{F}$, juvenile female, ventral view; $\mathbf{G}$, another cryptoniscus larva (or larvae) settles and transforms into a dwarf male; $\mathbf{H}$, host G. spinifer with ovigerous female $P$. ostendensis (in grey) occupying the marsupium; I, ovigerous female, lateral view with one dwarf male partially visible and eggs shown in dashed circles; $\mathbf{J}-\mathbf{M}$, developmental series of females of $P$. ostendensis, all in lateral view: $\mathbf{J}$, cryptoniscus larva with oral sucker (OS); K, early juvenile female (second phase fide Gilson 1909); L, later juvenile female (third phase fide Gilson 1909); $\mathbf{M}$, ovigerous female; N-R, proposed developmental series of females of Akrophryxus milvus n. gen., n. sp. and Telephryxus clypeus n. gen., n. sp.; N, cryptoniscus larva of T. clypeus n. gen., n. sp., dorsal view; $\mathbf{O}$, hypothetical early juvenile female, lateral view; $\mathbf{P}$, hypothetical later juvenile female of $A$. milvus n. gen., n. sp. attached to antennule of host (shown in grey), lateral view; $\mathbf{Q}$, ovigerous female of $A$. milvus n. gen., $\mathrm{n}$. sp. attached to antennule of host (shown in grey), lateral view; $\mathbf{R}$, ovigerous female of $A$. milvus n. gen., n. sp. dissected to show attachment to antennule of host (shown in grey) with mouth (Mo) of parasite noted, lateral view (A, B, D-M, modified from figures in Gilson (1909); C, from G. O. Sars (1898)). Scale bars: A Q, R, 1 mm; E, 3 mm; N, 100 um; rest not to scale. 
TABLE 1. - Comparative characters of females in the 20 genera of Dajidae G. O. Sars, 1883. Higher level host taxon and the position on hosts or attachment site of the parasites, if known, is indicated in the first column. Two genera have no described females. Species of Dolichophryxus Schultz, 1977 and Paraspidophryxus Schultz, 1977 described from cryptoniscus larva only, hosts are unknown.

\begin{tabular}{|c|c|c|c|c|c|c|c|c|}
\hline Genus & $\begin{array}{l}\text { Host taxon } \\
\text { (position on host) }\end{array}$ & $\begin{array}{l}\text { Distinct } \\
\text { cephalon }\end{array}$ & $\begin{array}{l}\text { Pereon } \\
\text { Segmented }\end{array}$ & $\begin{array}{l}\text { Number of } \\
\text { pereopod } \\
\text { pairs }\end{array}$ & $\begin{array}{l}\text { Number of } \\
\text { oostegite } \\
\text { pairs }\end{array}$ & $\begin{array}{l}\text { Number of } \\
\text { pleomeres }\end{array}$ & $\begin{array}{l}\text { Number of } \\
\text { pleopod } \\
\text { pairs }\end{array}$ & Uropods \\
\hline Aegophila Bresciani, 1966 & $\begin{array}{l}\text { Isopoda } \\
\text { (pereopod) }\end{array}$ & Yes & Rudimentary & 5 & 5 & 1 (fused) & 0 & No \\
\hline Akrophryxus n. gen. & $\begin{array}{l}\text { Brachyura } \\
\text { (antennule) }\end{array}$ & No & No & 5 & 5 & $\begin{array}{l}1 \text { (fused } \\
\text { into plate) }\end{array}$ & 0 & No \\
\hline Allophryxus Koehler, 1911 & Unknown & Yes & Yes & 5 & 5 & 5 or 6 & 2 & Yes \\
\hline $\begin{array}{l}\text { Arthrophryxus } \\
\text { Richardson, 1908a }\end{array}$ & $\begin{array}{l}\text { Lophogastrida } \\
\text { (unknown) }\end{array}$ & Yes & Yes & 4 & 5 & 5 & 0 & No \\
\hline $\begin{array}{l}\text { Aspidophryxus } \\
\text { G. O. Sars, } 1883\end{array}$ & $\begin{array}{l}\text { Mysida } \\
\text { (between eyestalks, } \\
\text { carapace, thorax) }\end{array}$ & Yes & Rudimentary & 5 & 1 & $\begin{array}{l}1 \text { (fused; } \\
\text { vermiform) }\end{array}$ & 0 & No \\
\hline $\begin{array}{c}\text { Branchiophryxus } \\
\text { Caullery, } 1897\end{array}$ & $\begin{array}{l}\text { Euphausiacea } \\
\text { (gills) }\end{array}$ & No & Rudimentary & 4 & 4 & 1 (fused) & 0 & No \\
\hline $\begin{array}{l}\text { Colophryxus } \\
\text { Richardson, 1908b }\end{array}$ & Unknown & Yes & Yes & 5 & $?$ & 1 (fused) & 0 & No \\
\hline Dajus Krøyer, [1842] & $\begin{array}{l}\text { Mysida } \\
\text { (in marsupium) }\end{array}$ & Yes & Yes & 5 & 5 & 4 & $1+$ & Yes \\
\hline $\begin{array}{l}\text { Heterophryxus G. O. } \\
\text { Sars, } 1885\end{array}$ & $\begin{array}{l}\text { Euphausiacea } \\
\text { (eyestalks; attaches } \\
\text { with 5th pereopods) }\end{array}$ & No & Yes & $\begin{array}{l}5 \text { (terminal } \\
\text { pair highly } \\
\text { modified) }\end{array}$ & 5 & 1 (fused) & 0 & No \\
\hline $\begin{array}{l}\text { Holophryxus } \\
\text { Richardson, } 1905\end{array}$ & $\begin{array}{l}\text { Caridea \& } \\
\text { Sergestoidea } \\
\text { (carapace) }\end{array}$ & Yes & Rudimentary & 5 & 5 & 1 (fused) & 0 & No \\
\hline $\begin{array}{l}\text { Notophryxus G. O. } \\
\text { Sars, } 1883\end{array}$ & $\begin{array}{l}\text { Euphausiacea } \\
\text { (abdomen, carapace, } \\
\text { gill, pereopod) }\end{array}$ & Yes & Yes & 5 & 1 (fused) & 1 (fused) & 0 & No \\
\hline $\begin{array}{l}\text { Oculophryxus Shields \& } \\
\text { Gómez-Gutiérrez, } 1996\end{array}$ & $\begin{array}{l}\text { Euphausiacea } \\
\text { (eyestalks; attaches } \\
\text { with antennae) }\end{array}$ & No & Rudimentary & 4 & 1 (fused) & 1 (fused) & 0 & No \\
\hline Prodajus Bonnier, 1903 & $\begin{array}{l}\text { Mysida } \\
\text { (in marsupium) }\end{array}$ & Yes & No & 5 & 5 & 4 or 5 & 0 & Yes \\
\hline $\begin{array}{l}\text { Streptodajus Nierstrasz \& } \\
\text { Brender à Brandis, } 1923\end{array}$ & $\begin{array}{l}\text { Mysida } \\
\text { (unknown) }\end{array}$ & No & Yes & 5 & $?$ & $\begin{array}{l}1 \text { (fused, } \\
\text { with slight } \\
\text { dorsal } \\
\text { indications) }\end{array}$ & ) & No \\
\hline Telephryxus n. gen. & $\begin{array}{l}\text { Anomura } \\
\text { (antennule) }\end{array}$ & No & No & 5 & 5 & $\begin{array}{l}1 \text { (fused } \\
\text { into plate) }\end{array}$ & 0 & No \\
\hline $\begin{array}{l}\text { Zonophryxus } \\
\text { Richardson, } 1904\end{array}$ & $\begin{array}{l}\text { Caridea } \\
\text { (carapace) }\end{array}$ & No & Rudimentary & 5 & 5 & 1 (fused) & 1 & No \\
\hline
\end{tabular}

the lateral orientation that is typical for other epicarideans ("côte à côte" of Trilles 1999). The two segments can only be distinguished in lateral view (Taberly 1957a: fig. 1; Coyle \& Mueller 1981: fig. 1E). Some mature dajid larvae have been illustrated with what appear to be uniramous uropods (G. O. Sars 1898; Gilson 1909) but, as suggested by Taberly (1957a), these larvae may not have been observed in the proper orientation. Tattersall (1911) considered uniramous pleopods and uniramous uropods a defining characteristic for dajids; however, the key of Bourdon in Trilles (1999) is probably more accurate for dajid characters (pleopods and uropods both biramous).

The cryptoniscus larva of T. clypeus n. gen., n. sp. lacks an oral sucker, a characteristic found in most dajid species for which larvae have been examined (Fig. 11J). However, we think this represents a case where the attachment structure fell off prior to or during collection. As noted by Taberly (1957b), the oral sucker of dajids is easily detached. Other records of dajid cryptoniscus larvae lacking an oral sucker (e.g. Holophryxus alaskensis Richardson, 1905, Zonophryxus quinquidens Barnard, 1914) should be considered as possible instances where this structure was detached. Although Coyle \& Mueller (1981) collected several cryptoniscus larvae of $H$. alaskensis and reported they lacked an oral sucker, we suggest collection of new material of all such species is needed to confirm absence or presence of the oral sucker in cryptoniscus larvae across dajid taxa. 
TABLE 2. - Comparative characters of males in the 20 genera of Dajidae G. O. Sars, 1883 (five genera have no described males: Antephyra Schultz, 1978, Prophryxus Richardson, 1909, and Streptodajus Nierstrasz \& Brender à Brandis, 1923 are known from females only; species of Dolichophryxus Schultz, 1977 and Paraspidophryxus Schultz, 1977 are known from cryptoniscus larvae only).

\begin{tabular}{|c|c|c|c|c|c|c|}
\hline Genus & $\begin{array}{l}\text { Antennule } \\
\text { (= antenna 1) }\end{array}$ & $\begin{array}{l}\text { Antennae } \\
\text { (= antenna 2) }\end{array}$ & $\begin{array}{l}\text { Terminal } \\
\text { pereomere } \\
\text { fused with first } \\
\text { pleomere }\end{array}$ & $\begin{array}{l}\text { Number of } \\
\text { pereopod } \\
\text { pairs }\end{array}$ & $\begin{array}{l}\text { Number of } \\
\text { pleomeres }\end{array}$ & Uropods \\
\hline Aegophila Bresciani, 1966 & Single lobe & 2 or 4 segments & No & 7 & 1 (fused) & No \\
\hline Akrophryxus n. gen. & $3 ?$ segments & Single lobe & Yes & 6 & 1 (fused) & No \\
\hline Allophryxus Koehler, 1911 & Single lobe? & 5 segments & No & 7 & 4 (partly fused) & ) Rudimentary \\
\hline Arthrophryxus Richardson, 1908 & Unknown & Unknown & No & 7 & 6 & No \\
\hline Aspidophryxus G. O. Sars, 1883 & 1 or 2 segments & 8 or 9 segments & No & 7 & 1 (fused) & Yes \\
\hline Branchiophryxus Caullery, 1897 & $\begin{array}{l}\text { Rudimentary } \\
\text { (1 segment?) }\end{array}$ & 9 segments & Unknown & 7 & 1 (fused) & No \\
\hline Colophryxus Richardson, 1908 & Unknown & Unknown & No & 7 & 5 or 6 & No \\
\hline Dajus Krøyer, [1842] & $\begin{array}{l}\text { Rudimentary } \\
\text { (1 segment?) }\end{array}$ & 9 segments & No & 7 & 1 (fused) & Rudimentary \\
\hline Heterophryxus G. O. Sars, 1885 & 1-3 segments & 5 segments & No & 7 & 1 (fused) & No \\
\hline Holophryxus Richardson, 1905 & 1-3 segments & Longer, 1-3 segments? & Yes & 7 & 1 & No \\
\hline Notophryxus G. O. Sars, 1883 & 1 or 2 segments & 5 or 6 segments & No & 7 & 1 (fused) & No \\
\hline $\begin{array}{l}\text { Oculophryxus Shields \& Gómez- } \\
\text { Gutiérrez, } 1996\end{array}$ & 2 segments & 5 segments & Yes & 7 & 1 & No \\
\hline Prodajus Bonnier, 1903 & 2 segments & 5 or 6 segments & No & 7 & 1 or 2 & $\begin{array}{c}\text { Yes } \\
\text { (biramous) }\end{array}$ \\
\hline Telephryxus n. gen. & 1 large segment & 2 segments & No & $\begin{array}{c}6+\text { reduced } \\
\text { pair }\end{array}$ & 1 (fused) & No \\
\hline Zonophryxus Richardson, 1904 & 1 segment & 6 segments & No & 7 & 1 (fused) & No \\
\hline
\end{tabular}

\section{DISCUSSION}

Female epicaridean parasites exhibit an amazing degree of morphological diversity that has likely evolved as varied adaptations to their highly specialized parasitic lifestyle, from forms that are not widely divergent from the typical isopod bauplan (i.e., with seven clearly identifiable pereomeres and segmented pereopods) to those that are nearly unrecognizable as isopods to the untrained eye (i.e., exhibit a sac-like body lacking any segmentation) (e.g. Trilles 1999; Williams \& Boyko 2012; Buhl-Mortensen et al. 2020). The present study adds two new genera and three new species to the family Dajidae, increasing the total number of genera from 18 to 20 and bringing the total number of species in the family to 59 . The findings expand the morphological boundaries of dajids - a group of parasites historically known primarily from the carapaces of shrimp-like hosts and the marsupia of mysids (Boxshall \& Hayes 2019; Williams \& Bunkley-Williams 2019). The females of the two newly described genera are nearly perfect spheres encompassing a portion of the antennules of their decapod hosts, a position and morphology previously unknown among dajids (Table 1) and only rarely reported in some other groups of crustacean parasites (see review in Introduction). Although these unusual parasites show no external signs of being epicarideans, upon dissection they exhibit the characteristic five pairs of segmented pleopods and other taxonomically important features of dajids. The males of both species are similar to other dajids in most characters (Table 2); although they are found inside the brood chambers of their female partners, as are the males of many other dajid species, they are essentially entombed by the fusion of the female's pereomeres and pleon around the antennae of hosts. Although the females of both new genera are superficially similar in many aspects (Table 1), the males show distinct, generic-level differences (Table 2). The similarity of the females' spheroid morphology could either be due to a shared common ancestor or to convergent adaptations for parasitizing antennules of their hosts. More specimens and, ideally, molecular data would be needed to address these possibilities.

Dajid life cyles, such as that of Prodajus ostendensis Gilson, 1909 from the opossum shrimp host Gastrosaccus spinifer (Goës, 1864), show that the female parasites reach sexual maturity and release epicaridium larvae that seek out a calanoid copepod, pass through a microniscus larval stage that feeds on copepod hemolymph, and ultimately transform into a cryptoniscus larva that seeks out and settles on a definitive host (Fig. 11A-G). The cryptoniscus larva likely settles on the host (possibly in the branchial chamber) and then moves to its final destination (see Coyle \& Mueller 1981). Unlike in other epicaridean parasites that exhibit protandric hermaphroditism (Williams \& Boyko 2012), the cryptoniscus larvae of dajids are supposedly of separate sexes and males do not turn into females (Gilson 1909); larvae either become juvenile females (Fig. 11F) or males (Fig. 11G); this, however, needs more study for confirmation. Males move onto females, eventually entering the brood chamber and fertilizing the eggs of sexually mature females (Fig. 11A, H, I). Some researchers (Gómez-Gutiérrez et al. 2010; 2017) have suggested the cryptoniscus larvae of dajids can act as micropredators (feeding transiently on multiple hosts) but this has not been definitively demonstrated. 
Additionally, Gómez-Gutiérrez et al. (2017) stated that one of the three main feeding strategies for dajids was "eating the eggs from the crustacean's ovigerous sacs, which so far is only observed in Dajidae infesting mysids (Shimomura et al. 2005; Shimomura \& Ohtsuka 2008)." No such observation was reported by either Shimomura et al. (2005) or Shimomura \& Ohtsuka (2008). However, Ohtsuka et al. (2007) reported on a copepod (Neomysidion rahotsu Ohtsuka, Boxshall \& Harada, 2005) that competed with a dajid (Prodajus curviabdominalis Shimomura, Ohtsuka \& Saito, 2005) for space in a mysid marsupium. This copepod was indeed observed to consume mysid eggs and Ohtsuka et al. (2007) stated "both of these parasites [dajid and copepod] utilise the lumen of the mysid marsupium as a microhabitat and its eggs (and embryos) as food (Ohtsuka et al. 2005; Shimomura et al. 2005)" but, once again, there is no data given in Ohtsuka et al. (2007) or either of the papers cited therein to show that dajids actually consume eggs. The sentence in Ohtsuka et al. (2007) "No host eggs remained when a fully mature female isopod was present within the marsupium, suggesting that all eggs in a brood were consumed by the isopod" indicates that these authors were speculating on the reason for the lack of host eggs and did not actually observe any predation by the dajids and that the copepod is the only egg predator in this relationship. We are unaware of any published data showing that dajids consume host eggs, although some cryptoniscoids are known to do so (reviewed in Buhl-Mortensen et al. 2020).

We propose the hypothetical life cycle and developmental transformation as the pathway by which females of Akrophryxus milvus n. gen., n. sp. and Telephryxus clypeus n. gen., n. sp. come to exhibit their spheroid morphology. In both new taxa, the life cycle is similar to that described above for dajids in general (Fig. 11A-G). However, the cryptoniscus larvae (Fig. 11N) either settle in the branchial chamber and then move onto the antennule or they may settle directly on an antennule. After attachment using their pereopods (and possibly the oral sucker) to the antennule, the body of a cryptoniscus larva that is transitioning to a juvenile female begins to dorsoventrally flex and the sides of the body expand (Fig. 11O). Eventually the pleon meets the anterior end and the two coalesce, as do the sides of the body (Fig. 11P). Thus, the plate (or "shield") partially surrounding the host antennule appears to be a highly modified pleon which gradually surrounds the host antennule during development of the parasite (Fig. 11P-R). Alternatively, the plate could be an anterior extension of the cephalon or sides of the body. These appear less likely scenarios considering the shape and orientation of the features. The holes in the plate (Figs 4 ; 7) represent areas where complete fusion between the cephalon, pleon, and sides of the body has not occurred yet and it is through these openings that the epicaridium larvae of the dajids are likely released. The males reside in the brood chamber of females (as seen in many other dajids although, as mentioned, they are trapped by the fusion of the female body) and fertilize the brood (Gilson 1909). The feeding biology and nutrition of males remains unknown; they may be non-feeding and derive nutrition from stores remaining from the cryptoniscus larval stage.
The male and larval characters (epicaridium and cryptoniscus larvae) display characteristic dajid features. However, the males are unique in their degree of posterior pereopod reduction: lacking a seventh pereopod (Akrophryxus milvus n. gen., n. sp.) or seventh pereopod reduced to one or two stub-like segments (Telephryxus clypeus n. gen., n. sp.), a feature previously recorded in only one other dajid (Oculophryxus bicaulis, with the seventh pereopod reduced to two elongate segments). Finally, the cryptoniscus larval specimen of T. clypeus n. gen., n. sp. did not possess an oral sucker, but we suggest this is likely an artifact due to loss of the structure during handling as the suckers are fragile and break off easily (see Taberly 1957b). Future research should examine the life history of these species to document the changes in form of the female through development to sexual maturity and verify the ontogenetic origin of the plate partially surrounding the host antennule (see Fig. 11N-R), as well as clear up remaining questions on larval characters, such as the presence or absence of a sucker in the cryptoniscus stage and the characters of molted (second stage) epicaridium larvae.

The abyssopelagic specimens of $T$. clypeus n. gen., n. sp., being found on a host collected from 4956-4997 m, are the deepest known of any dajid species; the prior record was the type specimens of Arthrophryxus beringanus Richardson, 1908, found at 2700 fathoms $(4938 \mathrm{~m})$ in the Bering Sea parasitizing Eucopia australis Dana, 1852 [Peracarida: Lophogastrida] (Richardson, 1908a). In fact, there is only one record of any epicaridean from deeper waters, that of Pleurocryptella altalis Williams, Boyko \& Marin, 2020 found on a Munidopsis petalorhyncha Baba, 2005 (originally as M. subsquamosa Birstein \& Zarenkov, 1970) [Anomura: Munidopsidae] from the KurileKamchatka Trench at 5025-5210 m depth (Birstein \& Zarenkov 1970 ; Williams et al. 2020).

Due to the fact that these are parasites of deep-water hosts, it is unlikely that any questions regarding ontogeny can be tested experimentally (i.e., via rearing). Instead, these questions will most likely need to be addressed with newly fixed material of these dajids in their various larval and developmental stages as obtained from other studies. We therefore urge researchers to retain decapods with unidentified parasites, particularly those found on antennules, properly fix them for morphological and molecular studies and, most critically, deposit them in museums for later analysis.

\section{Acknowledgements}

We thank Karen Osborn and Karen Reed (USNM) as well as Laure Corbari and Paula Martin-Lefevre (MNHN) for loan of specimens. The MNHN gives access to the collections in the framework of the RECOLNAT national Research Infrastructure. The ATIMO VATAE expedition was part of a cluster of Mozambique-Madagascar 2009-2010 expeditions under the umbrella of the "Our Planet Reviewed" programme conducted by Muséum national d'Histoire naturelle (MNHN; Principal Investigator Philippe Bouchet) and Pro Natura International (PNI) in partnership with Institut d'Halieutique et des Sciences Marines, University of Toliara (IH.SM) and the Madagascar 
bureau of Wildlife Conservation Society (WCS). The organizers thank the Total, Prince Albert II and Niarchos Foundations for their funding the expeditions. We would also like to thank the efforts of Flavio de Almeida Alves-Júnior (Universidade Federal de Pernambuco) and Jaime Gómez-Gutiérrez (Instituto Politécnico Nacional, Centro Interdisciplinario de Ciencias Marinas (CICIMAR)), for their reviews of the manuscript. This research was supported, in part, by a grant to JDW from the National Science Foundation (DBI-1337525).

\section{REFERENCES}

Almeida Alves-Júnior F. De, Bertrand A., De Carvalho Paiva R. J. \& De Souza-Filho J. F. 2019. - First report of the ectoparasitic Isopod, Holophryxus acanthephyrae Stephensen 1912 (Cymothoida: Dajidae) in the south Atlantic: recovered from a new host, the deep-sea shrimp, Acanthephyra acanthitelsonis Spence Bate, 1888. Thalassas: An International Journal of Marine Sciences 35: 13-15. https://doi.org/10.1007/s41208-018-0072-3

ANONYMOUS. 1907. - Dredging and hydrographic records of the U.S. Fisheries steamer Albatross for 1906. Bureau of Fisheries Document 621: 1-50.

BAEzA J., OCAMPO E. \& Luppi T. 2018. — The Life Cycle of Symbiotic Crustaceans: A Primer, in Thiel M. \& Wellborn G. A. (eds), The Natural History of the Crustacea: Life Histories. Oxford University Press, NY: 375-402.

Baillie C., Welicky R. L., Hadfield K. A., Smit N. J., Mariani S. \& BECK R. M. 2019. - Hooked on you: shape of attachment structures in cymothoid isopods reflects parasitic strategy. BMC Evolutionary Biology 19: 207. https://doi.org/10.1186/ s12862-019-1533-x

Birstein Y. A. \& ZarenKov N. A. 1970. - Bottom decapods (Crustacea Decapoda) of the Kurile-Kamchatka Trench area. Akademiya Nauk SSSR. Trudy Instituta Okeanologii im. P. P. Shirshova 86: 420-426.

BONNIER J. 1903. - Sur deux types nouveaux d'épicarides parasites d'un cumacé et d'un schizopode. Comptes Rendus Hebdomadaires des Séances de l'Académie de Sciences 136: 102-103.

BoXSHALL G. 2005a. - Copepoda (copepods), in ROHDE K. (ed), Ecology of Marine Parasites. CSIRO Publishing, Victoria: 123-137.

Boxshall G. 2005b. - Branchiura (fish lice), in RoHDE K. (ed), Ecology of Marine Parasites. CSIRO Publishing, Victoria: 145-146.

BOXSHALL G. 2005c. - Tantulocarida (tantulocarids), in RoHDE K. (ed), Ecology of Marine Parasites. CSIRO Publishing, Victoria: $147-148$.

Boxshall G. \& Halsey S. H. 2004. - An Introduction to Copepod Diversity. London, Ray Society, 966 p.

BOXSHALl G. A. \& HARRISON K. 1988. - New nicothoid copepods (Copepoda: Siphonostomatoida) from an amphipod and from deep-sea isopods. Bulletin of the British Museum (Natural History), Zoology 54: 285-299.

BoXshall G. \& HAYES P. 2019. - Chapter 3. Biodiversity and taxonomy of the parasitic Crustacea, in SMIT N. J., BRUCE N. L. \& HAdFIELd K. A. (eds), Parasitic Crustacea. Zoological Monographs Volume 3. Springer, Switzerland: 73-134.

Boxshall G. A. \& VADER W. 1993. - A new genus of Tantulocarida (Crustacea) parasitic on an amphipod host from the North Sea. Journal of Natural History 27: 977-988. https://doi. org/10.1080/00222939300770601

Boyko C. B., Bruce N. L., Hadfield K. A., Merrin K. L., Ota Y., Poore G. C. B., Taiti S., Schotte M. \& Wilson G. D. F. (eds). 2008a onwards. - World Marine, Freshwater and Terrestrial Isopod Crustaceans Database. Bopyridae Rafinesque, 1815. Accessed through: World Register of Marine Species at: http:// www. marinespecies.org/aphia.php? $\mathrm{p}=$ taxdetails\&id=1195 (con- sulted on 2020-02-11)

Boyko C. B., Bruce N. L., Hadfield K. A., Merrin K. L., Ota Y., Poore G. C. B., Taiti S., Schotte M. \& Wilson G. D. F. (EDS). 2008b onwards. - World Marine, Freshwater and Terrestrial Isopod Crustaceans database. Aega symmetrica Richardson, 1905. Accessed through: World Register of Marine Species at: http:// www. marinespecies.org/aphia.php? $\mathrm{p}=$ taxdetails\&id $=1288828$ (consulted on 2020-02-02).

Boyko C. B., Moss J., Williams J. D. \& Shields J. D. 2013. A molecular phylogeny of Bopyroidea and Cryptoniscoidea (Crustacea: Isopoda). Systematics and Biodiversity 11: 495-506. https://doi.org/10.1080/14772000.2013.865679

Boyko C. B., Williams J. W. \& Rhodes A. In Press. - First record of a tantulocaridan, Microdajus sp. (Crustacea: Tantulocarida), from the northwestern Atlantic. Nauplius.

BRESCIANI J. 1966. - Aegophila socialis gen. et sp. nov., an epicaridean parasitic on the isopod Aega ventrosa Sars. Ophelia 3: 99-112, pls 3-4. https://doi.org/10.1080/00785326.1966.10409636

Buhl-Mortensen L., Williams J. D. \& BOYKo C. B. 2020. A new species of Crinoniscus Pérez, 1900 (Crustacea: Isopoda: Crinoniscidae) parasitising the pedunculate barnacle Heteralepas newmani Buhl-Mortensen \& Mifsud (Cirripedia: Heteralepadidae) with notes on its ecology and a review of the genus. Systematic Parasitology. https://doi.org/10.1007/s11230-020-09903-x

CASTRO P. 2013. - Brachyuran crabs (Crustacea, Brachyura: Crossotonotidae, Ethusidae, Euryplacidae, Goneplacidae, Latreilliidae, Palicidae, Tetraliidae, Trapeziidae) of the MAINBAZA, MIRIKI, and ATIMO VATAE Expeditions to the Mozambique Channel and Madagascar, in AHYONG S. T., CHAN T.-Y., CORBARI L. \& NG P. K. L. (eds), Tropical Deep-Sea Benthos volume 27. Muséum national d'Histoire naturelle, Paris, 501 p. (Mémoires du Muséum national d'Histoire naturelle ; 204) 4: 437-466.

CAUllery M. 1897. — Branchiophryxus nyctiphanae, n. gen., n. sp., épicarde nouveau de la famille des Dajidae. Zoologischer Anzeiger 20: 88-92.

Cericola M. J. \& Williams J. D. 2015. - Prevalence, reproduction and morphology of the parasitic isopod Athelges takanoshimensis Ishii, 1914 (Isopoda: Bopyridae) from Hong Kong hermit crabs. Marine Biology Research 11: 236-252. https://doi.org/10.1080/ 17451000.2014 .928415

Coyle K. O. \& Mueller G. J. 1981. — Larval and juvenile stages of the isopod Holophryxus alaskensis (Epicarida, Dajidae) parasitic on decapods. Canadian Journal of Fisheries and Aquatic Sciences 38: 1438-1443. https://doi.org/10.1139/f81-190

FIELD L. H. 1969. - The biology of Notophryxus Lateralis (Isopoda: Epicaridea), parasitic on the euphausiid Nematoscelis difficilis. Journal of Parasitology 55: 1271-1277. https://doi.org/10.2307/3277273

GiLSON G. 1909. - Prodajus ostendensis n. sp. étude monographique d'un epicaride parasite du Gastrosaccus spinifer Goes. Bulletin scientifique de la France et de la Belgique 43: 19-92, pls 1-2.

GómeZ-GuTiérRez J., Robinson C. J., KaWAGUCHI S., \& Nicol S. 2010. - Parasite diversity of Nyctiphanes simplex and Nematoscelis difficilis (Crustacea: Euphausiacea) along the northwestern coast of Mexico. Diseases of Aquatic Organisms 88: 249-266. https:// doi.org/10.3354/dao02155

Gómez-Gutiérrez J., Morales-Ávila J.r., \& KaWaguchi S. 2017. - Chapter 7, Animalia, in GÓMEZ-GUTIÉRREZ J., MORALESÁviLA J.R., KAWAGUCHI S. (eds), Global Diversity and Ecological Function of Parasites of Euphausiids. Springer, Cham, 133-197.

GORE R. H. 1983. - Notes on rare species of Munidopsis (Anomura: Galatheidae) and Ethusina (Brachyura: Dorippidae) collected by the USNS Bartlett in the Venezuela Basin, Caribbean Sea. Proceedings of the Academy of Natural Sciences of Philadelphia 135: 200-217.

GoudeaU M. 1977. — Contribution a la biologie d'un crustacé parasite: Hemioniscus balani Buchholz, isopode épicaride. Nutrition, mues et croissance de la femelle et des embryons. Cahiers de Biologie Marine 18: 202-242, pls 1-4. 
Greve L. 1965. - A new epicaridean from western Norway, parasite on Tanaidacea. Sarsia 20: 15-19. https://doi.org/10.1080/0 0364827.1965 .10409552

Grygier M. J. \& Sieg J. 1988. — Microdajus (Crustacea: Tantulocarida) parasitic on an Antarctic tanaidacean, and a range extention of M. langi Greve. Journal of Natural History 22: 1495-1505. https://doi.org/10.1080/00222938800770921

HäFELE F. 1911. - Notizen über phylogenetisch interessante rhizocephalen. Zoologischer Anzeiger 38: 180-185.

Heiner I. \& Kristensen R. M. 2005. - Cycliophora (wheel wearers), in ROHDE K. (ed), Ecology of Marine Parasites. CSIRO Publishing, Victoria, 202-204.

Hiller A., Williams J. D. \& BOYKO C. B. 2015. — Description of two new species of Indo-Pacific Thylacoplethus and a new record of Thompsonia Japonica (Rhizocephala: Akentrogonida: Thompsoniidae) from hermit, porcelain, and mud Crabs (Decapoda) based on morphological and molecular data. Journal of Crustacean Biology 35: 202-215. https://doi.org/10.1163/1937240X-00002330

HøEG J. T. \& LÜTZEN J. 1995. - Life cycle and reproduction in the Cirripedia Rhizocephala. Oceanography and Marine Biology: An Annual Review 33: 427-485.

Huys R., Boxshall G. A. \& Lincoln R. J. 1993. - The tantulocaridan life cycle: the circle closed? Journal of Crustacean Biology 13: 434-442.

KAKUI K. 2016. - Descriptions of two new species of Rhizorhina Hansen, 1892 (Copepoda: Siphonostomatoida: Nicothoidae) parasitic on tanaidacean crustaceans, with a note on their phylogenetic position. Systematic Parasitology 93: 57-68. https://doi. org/10.1007/s11230-015-9604-x

KoEHLER R. 1911. - Isopodes nouveaux de la famille des dajidés provenant des campagnes de La $<$ Princesse-Alice $>$. Bulletin de l'Institut Océanographique (Fondation Albert Ier, Prince de Monaco) 196: 1-34.

Kolbasov G. A. \& SAVCHENKO A. S. 2009. - Microdajus tchesunovi sp. n. (Tantulocarida, Microdajidae) - a new crustacean parasite of from [sic] the White Sea. Experimental Parasitology 125: 13-22. https://doi.org/10.1016/j.exppara.2009.08.009

Kossmann R. 1880. - III. Malacostraca. Zoologische Ergebnisse Einer im Auftrage der Königlichen Acadmie der Wissenschaften zu Berlin Ausgeführten Reise in die Küstengebiete des Rothen Meeres, Zweite Hälfte, Erste Lieferung. Leipzig: Wilhelm Engelmann.

Kossmann R. 1881. — Die Entonisciden. Mittheilungen aus der Zoologischen Station zu Neapel 3: 149-169, pls 8-9.

Krøyer H. [1842]. - Zoologie. Crustacés, in Gaimard P. (ed), Voyages de la Commission Scientifique du Nord en Scandinavie, en Laponie au Spitzberg et aux Faröe Pendant les Années 1838, 1839 et 1840 sur la Corvette la Recherche Commandée par M. Fabvre Lieutenant de Vasseau, Paris: Arthus Bertrand, pls 1-5, 5a, 6-11, 11b, 13-20, 22-31, 35-43 (no text).

LinCOLN R. J. \& BoxSHALl G. A. 1983. — Deep-sea asellote isopods of the north-east Atlantic: the family Dendrotionidae and some new ectoparasitic copepods. Zoological Journal of the Linnean Society 79: 297-318. https://doi.org/10.1111/j.1096-3642.1983. tb01168.x

LOM J. 2005. - Ciliophora (ciliates), in RoHDE K. (ed), Ecology of Marine Parasites. CSIRO Publishing, Victoria, 37-40.

MARKHAM J. C. 1985. - A review of the bopyrid isopods infesting caridean shrimps in the northwestern Atlantic Ocean, with special reference to those collected during the Hourglass cruises in the Gulf of Mexico. Memoirs of the Hourglass Cruises 7: 1-156.

Milne Edwards H. 1840. - Histoire Naturelle des Crustacés, Comprenant l'Anatomie, la Physiologie et la Classification de ces Animaux. Volume 3. Paris: Librairie Encyclopédique de Roret.

Nierstrasz H. F. \& Brender À Brandis G. A. 1923. - Die isopoden der Siboga-Expedition. II. Isopoda genuina. I. Epicaridea. Siboga-Expeditie 32b: 57-121, pls 4-9.

Nierstrasz H. F. \& Brender À Brandis G. A. 1931. - Papers from Dr Th. Mortensen's Pacific Expedition 1914-16. LVII.
Epicaridea II. Videnskabelige Meddedelser dfa den Dansk Naturhistoriske Forening i København 91: 147-226, pl. 1.

OHTSUKa S., Boxshall G. A. \& Harada S. 2005. - A new genus and species of nicothoid copepod (Crustacea: Copepoda: Siphonostomatoida) parasitic on the mysid Siriella okadai Ii from off Japan. Systematic Parasitology 62: 65-81. https://doi.org/10.1007/ s11230-005-5483-x

OhtsuKa S., Harada S., Shimomura M., Boxshal G. A., Yoshizaki R., UENO D., NITTA Y., IWASAKI S., OKAWACHI H. \&SAKAKIHARA T. 2007. - Temporal partitioning: dynamics of alternating occupancy of a host microhabitat by two different crustacean parasites. Marine Ecology Progress Series 348: 261-272. https:// doi.org/10.3354/meps07096

RAFINESQUe C. S. 1815. - Analyse de la Nature ou Tableau de l'Univers et des Corps Organisés. Palerme. https://doi.org/10.5962/ bhl.title.106607

RICHARDSON H. 1904. - Contributions to the natural history of the Isopoda. [Second part]. Proceedings of the United States National Museum 27: 657-681. https://doi.org/10.5479/si.00963801.271369.657

RichARDSON H. 1905. - Isopods from the Alaska Salmon Investigation. Bulletin of the Bureau of Fisheries 24: 209-221.

RICHARDSON H. 1908a. - On some isopods of the family Dajidae from northwest Pacific Ocean with descriptions of a new genus and two new species. Proceedings of the United States National Museum 33: 689-696. https://doi.org/10.5479/si.00963801.331586.689

RICHARDSON H. 1908b. - Description of a new isopod genus of the family Dajidae. Proceedings of the United States National Museum 34: 391-392. https://doi.org/10.5479/si.00963801.34-1618.391

RiCHARDSON H. 1909. - Isopods collected in the northwest Pacific by the U. S. Bureau of Fisheries Steamer 'Albatross' in 1906. Proceedings of the United States National Museum 37: 75-129. https://doi.org/10.5479/si.00963801.37-1701.75

RusTAD D. 1935. - Notes on Holophryxus richardi [sic] Koehler(?) (Fam. Dajidae). Bergens Museums Arbok 1934: 1-31.

SARS G. O. 1883. - Oversigt af Norges crustaceer med foreløbige bemaerkninger over de nye eller mindre bekjendte arter. I. (Podophthalmata - Cumacea - Isopoda - Amphipoda). Forhandlinger $i$ Videnskabs-Selskabet $i$ Christiania for 1882: $1-124$, pls $1-6$.

SARS G. O. 1885. - Report on the Schizopoda collected by H.M.S. Challenger during the years 1873-76. Report on the Scientific Results of the Voyage of the H.M.S. Challenger During the Years 1873-76 Under the Command of Captain George S. Nares, R.N., F.R.S. and the Late Captain Frank Tourle Thomson, R.N. Zoology 13 (37): 1-228, pls 1-38.

SARS G. O. 1896-1899. - An Account of the Crustacea of Norway with Short Descriptions and Figures of All the Species. Volume II. Isopoda. Bergen: Bergen Museum. [Dajid text and plates published in 1898.]

SHIELDS \& GÓMEZ-GUTIÉRREZ 1996. - Oculophryxus bicaulis, a new genus and species of dajid isopod parasitic on the euphausid Stylocheiron affine Hansen. International Journal for Parasitology 26: 261-268. https://doi.org/10.1016/0020-7519(95)00126-3

Shimomura M., OHTSUKa S. \& Naito K. 2005. - Prodajus curviabdominalis $\mathrm{n}$. sp. (Isoposa: Epicaridea: Dajidae), an ectoparasite of mysids, with notes on morphological changes, behaviour and life-cycle. Systematic Parasitology 60: 39-57. https://doi. org/10.1007/s11230-004-1375-8

SHIMOMURA M. \& OHTSUKA S. 2008. — New record of a euphausiid isopod, Heterophryxus appendiculatus G. O. Sars, 1885 (Crustacea: Dajidae) from Japan. Proceedings of the Biological Society of Washington 121: 326-330. https://doi.org/10.2988/07-09.1

Schultz G. A. 1978. - Biology of the Antarctic Seas VII. 3. More planktonic isopod crustaceans from from subantarctic and Antarctic seas. Antarctic Research Series 27: 69-89.

SMIT N. J., BRUCE N. L. \& HAdFIELD K. A. 2014. — Global diversity 
of fish parasitic isopod crustaceans of the family Cymothoidae. International Journal for Parasitology: Parasites and Wildlife 3: 188-197. https://doi.org/10.1016/j.ijppaw.2014.03.004

STEPHENSEN K. 1913 - Report on the Malacostraca collected by the "Tjalfe"-expedition, under the direction of Ad. S. Jensen, especially at W. Greenland. Videnskabelige meddelelser fra Dansk naturhistorisk forening i Kjøbenhavn: 64: 57-134.

STRÖMBERG J.-O. 1971. - Contribution to the embryology of bopyrid isopods with special reference to Bopyroides, Hemiarthrus and Peseudione (sic) (Isopoda, Epicaridea). Sarsia 47: 1-47.

TABERLY G. 1957a. — Étude morphologique d'un Dajidae peu connu: Prodajus lobiancoi Bonnier (Crust. Isop. Epicaridae) 1. - L'épicardium de P. lobiancoi et remarques générales sur l'épicardium des Dajidae. Bulletin d'Institut océanographique 1045: 1-12.

TABERLY G. 1957b. - Étude morphologique d'un Dajidae peu connu : Prodajus lobiancoi Bonnier (Crust. Isop. Epicaridae) II. - Le cryptoniscium de P. lobiancoi et sa mue formes connues de cryptoniscium de Dajidae. Bulletin d'Institut océanographique 1049: 1-15.

TATTERSAll W. M. 1911. — Die Nordischen Isopoden. Vol. Zoologischer Teil 3, Band 6: Crustacea. Lieferung 14. Nordisches Plankton. Kiel \& Leipzig: Lipsius \& Tischer.
TRILles J.-P. 1999. — Ordre des isopodes sous-ordre des épicarides (Epicaridea Latreille, 1825), in FOREST J. (ed.), Traité de Zoologie. Anatomie, Systématique, Biologie (Pierre-P. Grassé). Tome VII, Fascicule III A, Crustacés Péracarides. Mémoires de l'Institut Oceanographique, Monaco 19: 279-352.

WASMER R. A. 1988. - The parasitic isopod Holophryxus acanthephyrae Stephensen (Epicaridea: Dajidae) from the subantarctic south Pacific, with notes on its synonymy and host. Proceedings of the Biological Society of Washington 101: 20-30.

Williams E. H. \& BunKLEY-Williams L. 2019. - Chapter 5. Life cycle and life history strategies of parasitic Crustacea, in Smit N. J., Bruce N. L. \& Hadfield K. A. (eds), Parasitic Crustacea. Zoological Monographs Volume 3. Springer, Switzerland: $179-266$

Williams J. D. \& BoyKo C. B. 2012. - The global diversity of parasitic isopods associated with crustacean hosts (Isopoda: Bopyroidea and Cryptoniscoidea). PLoS ONE 7: e35350. https://doi. org/10.1371/journal.pone.0035350

Williams J. D., Boyko C. B. \& Marin I. N. 2020. - A new species and depth record of bopyrid (Crustacea, Isopoda) from a squat lobster in the Kuril-Kamchatka Trench. European Journal of Taxonomy 724: 122-133. https://doi.org/10.5852/ ejt.2020.724.1165 